\title{
Histamine H1 Receptor Contributes to Vestibular Compensation
}

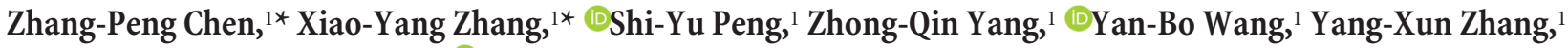 \\ $\mathrm{Xi}$ Chen, ${ }^{1}$ Jian-Jun Wang, ${ }^{1,2}$ and ${ }^{-}$Jing-Ning $\mathrm{Zhu}^{1,2}$ \\ ${ }^{1}$ State Key Laboratory of Pharmaceutical Biotechnology and Department of Physiology, School of Life Sciences, and ${ }^{2}$ Institute for Brain Sciences, Nanjing \\ University, Nanjing 210023, China
}

Vestibular compensation is responsible for the spontaneous recovery of postural, locomotor, and oculomotor dysfunctions in patients with peripheral vestibular lesion or posterior circulation stroke. Mechanism investigation of vestibular compensation is of great importance in both facilitating recovery of vestibular function and understanding the postlesion functional plasticity in the adult CNS. Here, we report that postsynaptic histamine $\mathrm{H} 1$ receptor contributes greatly to facilitating vestibular compensation. The expression of $\mathrm{H} 1$ receptor is restrictedly increased in the ipsilesional rather than contralesional GABAergic projection neurons in the medial vestibular nucleus (MVN), one of the most important centers for vestibular compensation, in unilateral labyrinthectomized male rats. Furthermore, H1 receptor mediates an asymmetric excitation of the commissural GABAergic but not glutamatergic neurons in the ipsilesional MVN, which may help to rebalance bilateral vestibular systems and promote vestibular compensation. Selective blockage of H1 receptor in the MVN significantly retards the recovery of both static and dynamic vestibular symptoms following unilateral labyrinthectomy, and remarkably attenuates the facilitation of betahistine, whose effect has traditionally been attributed to its antagonistic action on the presynaptic $\mathrm{H} 3$ receptor, on vestibular compensation. These results reveal a previously unknown role for histamine $\mathrm{H} 1 \mathrm{receptor}$ in vestibular compensation and amelioration of vestibular motor deficits, as well as an involvement of $\mathrm{H} 1$ receptor in potential therapeutic effects of betahistine. The findings provide not only a new insight into the postlesion neuronal circuit plasticity and functional recovery in the CNS, but also a novel potential therapeutic target for vestibular disorders.

Key words: commissural inhibitory system; $\mathrm{H} 1$ receptor; medial vestibular nucleus; unilateral labyrinthectomy; vestibular compensation

\section{Significance Statement}

Vestibular disorders manifest postural imbalance, nystagmus, and vertigo. Vestibular compensation is critical for facilitating recovery from vestibular disorders, and of great importance in understanding the postlesion functional plasticity in the adult CNS. Here, we show that postsynaptic $\mathrm{H} 1$ receptor in the medial vestibular nucleus (MVN) contributes greatly to the recovery of both static and dynamic symptoms following unilateral vestibular lesion. $\mathrm{H} 1$ receptor selectively mediates the asymmetric activation of commissural inhibitory system in the ipsilesional MVN and actively promotes vestibular compensation. The findings provide not only a new insight into the postlesion neuronal circuit plasticity and functional recovery of CNS, but also a novel potential therapeutic target for promoting vestibular compensation and ameliorating vestibular disorders.

\section{Introduction}

Vestibular disorders, characterized by postural imbalance, gaze instability, spatial disorientation, and vertigo, are common in the

Received May 28, 2018; revised 0ct. 29, 2018; accepted 0ct. 30, 2018.

Author contributions: Z.-P.C. and X.-Y.Z. wrote the first draft of the paper; J.-J.W. and J.-N.Z. designed research; Z.-P.C., X.-Y.Z., S.-Y.P., Z.-Q.Y., and Y.-B.W. performed research; Z.-P.C., X.-Y.Z., S.-Y.P., Y.-B.W., Y.-X.Z., and X.C. analyzed data; J.-J.W. and J.-N.Z. wrote the paper.

This work was supported by the National Natural Science Foundation of China (Grants 31330033, 81671107, 31471112, 31600834, and NSFC/RGC Joint Research Scheme 31461163001); the Ministry of Education of China (Fundamental Research Funds for the (entral Universities 020814380071 and 020814380091); the China Postdoctoral Science Foundation (Grant 2017T100351); and Nanjing University Innovation and Creative Program for Ph.D. candidate (Grant 2016026). general population and strongly affect the quality of life (Angelaki and Cullen, 2008; Sajjadi and Paparella, 2008; Ward and Zee, 2016; Brandt and Dieterich, 2017). Both peripheral vestibular abnormalities, such as benign paroxysmal positional vertigo, vestibular neuritis, and Meniere's disease, and central vestibular le-

The authors declare no competing financial interests.

*Z.-P.C. and X.-Y.Z. contributed equally to this work.

Correspondence should be addressed to either Dr. Jing-Ning Zhu or Dr. Jian-Jun Wang, State Key Laboratory of Pharmaceutical Biotechnology and Department of Physiology, School of Life Sciences, Nanjing University, 163 Xianlin Avenue, Nanjing 210023, China, E-mail: jnzhu@nju.edu.cn or jjwang@nju.edu.cn.

https://doi.org/10.1523/JNEUROSCI.1350-18.2018

Copyright $\odot 2019$ the authors $\quad 0270-6474 / 19 / 390420-14 \$ 15.00 / 0$ 
sions caused by posterior circulation stroke usually lead to vestibular syndromes (Sajjadi and Paparella, 2008; Chen et al., 2014; Kim and Zee, 2014). Interestingly, some of the vestibular syndromes caused by unilateral vestibular lesions are gradually ameliorated over time in both humans and animals. This process of natural recovery from vestibular deficits is known as vestibular compensation (Faulstich et al., 2006; Becker-Bense et al., 2013; Lacour et al., 2016; Zwergal et al., 2016). Facilitating vestibular compensation is an important beneficial strategy for the clinical treatment of vestibular dysfunctions (Straka et al., 2005; Macdougall and Curthoys, 2012; Lacour et al., 2016). On the other hand, vestibular compensation is a window for understanding the postlesion plasticity in the adult CNS (Zwergal et al., 2016) and distributed synergistic plasticity in the levels of synapses, neurons, and circuits may provide basis for behavioral compensation (Gao et al., 2012). However, neural mechanism underlying the vestibular compensation is still far from clear.

The central histaminergic system, originating exclusively from the tuberomammillary nucleus (TMN) of the hypothalamus, has long been implicated in vestibular functions and the recovery process following vestibular lesions (Tighilet et al., 2006; Haas et al., 2008; Panula and Nuutinen, 2013; Panula et al., 2015). Histamine-related drugs, especially betahistine, have been widely used in the treatment of vestibular disorders (Tighilet et al., 2005; Chazot, 2013; Lacour, 2013). Unlike the vestibular sedatives prescribed for symptomatic relief often interfere with the restoration of vestibular functions (Chabbert, 2016), betahistine has been supposed to promote and facilitate central vestibular compensation (Redon et al., 2011; Lacour, 2013). The effect of betahistine has traditionally been attributed to its antagonistic action on the presynaptic $\mathrm{H} 3$ receptor, which may serve as not only autoreceptor to inhibit histamine release but also heteroreceptor to modulate release of other neurotransmitters, particularly GABA (Tighilet et al., 2005; Bergquist et al., 2006). Notably, however, betahistine is also a weak agonist for postsynaptic histamine H1 receptor (Ali et al., 2010; Lian et al., 2016; Provensi et al., 2016). Yet little is known about the role of $\mathrm{H} 1$ receptor in the pathophysiology of vestibular disorders and the following vestibular compensation.

Several lines of evidence indicate that the histamine $\mathrm{H} 1$ receptor may directly participate in the recovery process after vestibular lesion. First, H1 receptor is expressed abundantly throughout the central vestibular nuclear complex, including the medial vestibular nucleus (MVN; Peng et al., 2013; X. Y. Zhang et al., 2013; Zhuang et al., 2013). Second, H1 receptor mediates a significant postsynaptic excitatory effect of histamine on vestibular nuclear neurons both in vitro and in vivo (Yabe et al., 1993; Wang and Dutia, 1995; Peng et al., 2013; X. Y. Zhang et al., 2013; Zhuang et al., 2013). Third, after unilateral labyrinthectomy (UL), elevated expression of $\mathrm{H} 1$ receptor in the MVN has been reported (Lacour and Tighilet, 2010; Zhou et al., 2013). Therefore, in the present study, using behavioral assessment combined with Western blot, retrograde tracing, immunostaining, and whole-cell patch-clamp recording, we determine the pathophysiological function of histamine $\mathrm{H} 1$ receptor in the vestibular compensation. We report here that postsynaptic $\mathrm{H} 1$ receptor in the MVN, one of the most important centers for vestibular compensation, plays a critical role in the recovery of both static and dynamic symptoms after unilateral peripheral vestibular lesion. $\mathrm{H} 1$ receptor selectively mediates the asymmetric activation of commissural inhibitory system in the circuit level and actively promotes rebalancing of bilateral vestibular systems and vestibular compensation.

\section{Materials and Methods}

Animals

Adult male Sprague-Dawley rats (Animal Care Facility at Nanjing Medical University, Jiangsu, China) were individually housed under a $12 \mathrm{~h}$ light/dark cycle, with ad libitum access to food and water. All experimental procedures were performed in accordance with the U.S. National Institutes of Health Guide for the Care and Use of Laboratory Animals (NIH Publication 85-23, revised 2011), and were approved by the Experimental Animal Care and Use Committee of Nanjing University. All efforts were made to minimize the number of animals used and their suffering.

\section{UL and vestibular compensation model}

UL was performed as previously described (Campos-Torres et al., 2005; Sadeghi et al., 2007; Li et al., 2013) to establish a model for vestibular compensation. Briefly, after anesthesia with sodium pentobarbital (40 $\mathrm{mg} / \mathrm{kg}$ ), a postauricular incision was made to expose the external ear canal and the tympanic bulla. The lateral wall of the tympanic bulla was opened with an otologic drill. The malleus and incus were removed with the aid of a microscope. Special attention was paid to avoid damage to the pterygopalatine artery. The oval window was then opened and enlarged. The vestibule was aspirated using a fine plastic suction pipette, destroyed by mechanical ablation, and then rinsed with $100 \%$ ethanol. Finally, the space created by the labyrinthectomy was packed with gelfoam (Ferrosan Medical Devices) and the skin wound was sutured. Sham-operated control rats were given a surgical sham treatment identical to the UL procedure, but without damage to the inner ear.

\section{Western blotting}

MVN tissue punches were carefully collected from coronal brain slices under microscope according to the rat brain atlas (Paxinos and Watson, 2014). Protein levels were analyzed via Western blotting using selective antibodies. Protein levels were normalized by probing the same blots with a GAPDH antibody. For Western blotting analysis, the following antibodies were used. Primary antibodies: a mouse anti-GAPDH (1:2000; Santa Cruz Biotechnology, catalog \#SC-365062; RRID: AB_10847862) and a rabbit anti-HRH1 (1:500; Santa Cruz Biotechnology, catalog \#SC-20633; RRID:AB_2277328). Second antibodies: horseradish peroxidase (HRP)-conjugated anti-mouse antibody (1:5000; Life Technologies, catalog \#62-6520; RRID:AB_2533947), HRP-conjugated anti-rabbit antibody (1:5000; Life Technologies, catalog \#65-6120; RRID:AB_2533967). Protein bands were analyzed using ImageJ software (NIH).

\section{Retrograde tracing}

The experimental procedures for retrograde tracing followed our previous reports (Li et al., 2017; Wang et al., 2017; Ji et al., 2018). Rats were anesthetized with sodium pentobarbital $(40 \mathrm{mg} / \mathrm{kg})$ and mounted on a stereotaxic frame under aseptic conditions. According to the rat brain atlas (Paxinos and Watson, 2014), a glass micropipette (10-15 $\mu \mathrm{m}$ in diameter in the tip) filled within $1 \mu$ l of retrograde tracer Fluoro-Gold (FG; $4 \%$ in saline; Fluorochrome) was planted into the MVN (A: $-10.9 \pm 0.3, \mathrm{~L}: 1.3 \pm 0.2$, and $\mathrm{H}: 5.8)$. The tracer was injected unilaterally using electrophoresis with a square wave pulse of $5-10 \mu \mathrm{A}$ at a rate of $7 \mathrm{~s}$ On/7 s Off for $30 \mathrm{~min}$. The glass micropipette was hold for $10 \mathrm{~min}$ after the injection. The immunohistochemical experiment was performed 3 weeks later to determine the injection site and location of retrogradely labeled cells.

\section{Immunofluorescence}

As previously reported ( X. Y. Zhang et al., 2013; J. Zhang et al., 2016; Wang et al., 2017; Zhuang et al., 2018a,b), sham or UL rats (1-4 d post-UL) were deeply anesthetized with sodium pentobarbital $(65 \mathrm{mg} /$ $\mathrm{kg}$ ) and perfused transcardially with $100 \mathrm{ml}$ normal saline, followed by $250-300 \mathrm{ml} 4 \%$ paraformaldehyde in $0.1 \mathrm{M}$ phosphate buffer. The brain was gently removed, trimmed, and postfixed in the same fixative for $12 \mathrm{~h}$ at $4^{\circ} \mathrm{C}$ and then cryoprotected with $30 \%$ sucrose for $48 \mathrm{~h}$. Frozen coronal sections ( $25 \mu \mathrm{m}$ thick) containing the MVN were acquired by a freezing microtome (CM 3050S, Leica) and mounted on gelatin-coated slides. The slices were rinsed with PBS containing $0.1 \%$ Triton X-100 and then incubated in $10 \%$ normal bovine serum in PBS containing $0.1 \%$ Triton 
$\mathrm{X}-100$ for $30 \mathrm{~min}$. Sections were incubated overnight at $4^{\circ} \mathrm{C}$ with primary antibodies: goat anti-HRH1 (1:200; Everest Biotechnology, catalog \#EB06904; RRID:AB_2230568), mouse anti-GAD67 (1:500; Millipore, catalog \#MAB5406; RRID:AB_2278725), mouse anti-Glutamate (1: 2000; Millipore, catalog \#MAB5304; RRID:AB_94698), and rabbit anti-FG (1:2000; Millipore, catalog \#AB153-I; RRID:AB_2632408). After a complete wash in PBS, the sections were incubated in the related secondary antibodies (1:2000; Invitrogen) conjugated to AlexaFluor 488 (catalog \#A-11055; RRID:AB_2534102), AlexaFluor 594 (catalog \#A21207; RRID:AB_141637), and AlexaFluor 350 (catalog \#A10035; RRID: $\left.A B \_2534011\right)$ for $2 \mathrm{~h}$ at room temperature in the dark. The slices were washed and mounted in Fluoromount-G mounting medium (SouthernBiotech). Incubations replacing the primary antiserum with control immunoglobulins and/or omitting the primary antiserum were used as negative controls. The micrographs were taken with inverted laser scanning confocal microscope TCS SP8 (Leica). Digital images from the microscope were recorded with LAS X Viewer Software (Leica). Image processing and labeling intensity quantification were performed with Image Pro Plus 6.0 software (Media Cybernetics) by an investigator who was blind to the group assignments.

\section{Whole-cell patch-clamp recordings and neuronal identification}

UL rats (1-4 d post-UL), which had been microinjected with FG in unilateral MVN 3 weeks previously, were used for whole-cell patchclamp recordings on the MVN commissural neurons. Coronal slices (300 $\mu \mathrm{M}$ in thickness) of brainstem containing the MVN were cut with a vibroslicer (VT $1200 \mathrm{~S}$, Leica). The slices were incubated in $95 \% \mathrm{O}_{2}$ and $5 \% \mathrm{CO}_{2}$ oxygenated artificial CSF (composition in mM: $124 \mathrm{NaCl}, 2.5$ $\mathrm{KCl}, 1.25 \mathrm{NaH}_{2} \mathrm{PO}_{4}, 1.3 \mathrm{MgSO}_{4}, 26 \mathrm{NaHCO}_{3}, 2 \mathrm{CaCl}_{2}$, and $10 \mathrm{D}$-glucose) at $35 \pm 0.5^{\circ} \mathrm{C}$ for at least $1 \mathrm{~h}$ before any experiment was started.

Whole-cell patch-clamp recordings were performed as previously described (J. Zhang et al., 2011; X. Y. Zhang et al., 2013; Zhuang et al., 2018a) on MVN neurons with borosilicate glass pipettes (3-5 M $\Omega$ ). Pipettes were filled with (in $\mathrm{mM}$ ): $140 \mathrm{~K}$-methylsulfate, $7 \mathrm{KCl}, 2 \mathrm{MgCl}_{2}, 10$ HEPES, 0.1 EGTA, $4 \mathrm{Na}_{2}$-ATP, 0.4 GTP-Tris, and 4\% biocytin (SigmaAldrich), pH 7.25. During recording sessions, MVN neurons were visualized with an Olympus BX51WI microscope (Olympus). The bright fluorescence signal of FG-positive neurons was detected using a xenon light source and an MTI-Dage CCD camera (IR-1000, Meyer Instruments). Patch-clamp recordings were acquired with an Axopatch-200B amplifier (Molecular Devices) and the signals were fed into a computer through a Digidata-1550 interface (Molecular Devices) for data capture and analysis (pClamp 8.2, Molecular Devices). Recordings of membrane potentials were low-pass filtered at $5 \mathrm{kHz}$ and digitized at $20 \mathrm{kHz}$.

For action potential analysis, the spikes were averaged together by alignment at their peaks. Spike threshold was defined as the membrane potential at which the voltage derivative reached $10 \mathrm{~V} / \mathrm{s}$. Spike half-width was measured at the halfway point between threshold and peak. The afterdepolarization (ADP) was quantified as the maximum value of the spike derivative during the $1 \mathrm{~ms}$ after the spike repolarized to threshold value.

The peristimulus time histograms (PSTHs) of the recorded neuronal discharges were generated by the software Spike 2 (CED) to assess the effects of histamine on the cells. We briefly $(1 \mathrm{~min})$ bathed the slices with histamine (1-100 $\mu \mathrm{M}$, Sigma-Aldrich) to stimulate the recorded neurons. Ranitidine $(0.3 \mu \mathrm{M}$, Alomone Labs) and iodophenpropit $(0.3 \mu \mathrm{M}$, Alomone Labs), selective antagonists for histamine $\mathrm{H} 2$ and $\mathrm{H} 3$ receptor, respectively, were coapplied to isolate the effect mediated by $\mathrm{H} 1$ receptor.

To identify whether the recorded neurons were commissural inhibitory or excitatory neurons, brain slices containing the biocytin-filled neurons in the whole-cell patch-clamp recordings were fixed, resectioned at $25 \mu \mathrm{m}$, and coimmunolabeled for FG and GAD67/glutamate, following the above immunofluorescence procedure.

\section{Drug administration and behavioral assessment}

Histamine $\mathrm{H} 1$ receptor antagonists, mepyramine $(0.05 \mathrm{mg} / \mathrm{kg}$; Tocris Bioscience)/fluorescent mepyramine (H1-BY633-AN, $0.05 \mathrm{mg} / \mathrm{kg}$; Sigma-Aldrich) and diphenhydramine $(25 \mathrm{mg} / \mathrm{kg}$; Sigma-Aldrich), as well as betahistine $(0.04 \mathrm{mg} / \mathrm{kg}$; Sigma-Aldrich), were microinjected into the MVN or given intraperitoneally (i.p.) once daily for $3 \mathrm{~d}$ after UL. For intra-MVN microinjections, two stainless-steel guide tubes [length: 1.1 mm, outer diameter (o.d.): $0.8 \mathrm{~mm}$, inner diameter: $0.5 \mathrm{~mm}$ ] were bilaterally implanted just above the MVN (A: $-10.9 \pm 0.3, \mathrm{~L}: 1.3 \pm 0.2$, and $\mathrm{H}: 3.8$ ) according to the rat brain atlas (Paxinos and Watson, 2014) following stereotactic brain surgery as we described previously (J. Zhang et al., 2011; Wang et al., 2017; Zhuang et al., 2018b). The UL and behavioral assessment were conducted at least $3 \mathrm{~d}$ after implantation.

In behavioral tests, static symptoms of vestibular imbalance, including postural asymmetry, head roll tilt and nystagmus, were scored by an assessor who was blinded to the groups after UL according to the previous reports (Bergquist et al., 2008; Günther et al., 2015). Each component was given a maximum score of 10 . Furthermore, recovery of dynamic motor function in UL rats was assessed by open field and rotarod tests. In addition, open field and negative geotaxis tests were applied to determine the baseline vestibular function in normal rats.

Postural asymmetry scoring. Postural deficits were scored as follows (Bergquist et al., 2008; Günther et al., 2015): spontaneous barrel rolling, 10 points; barrel rolling evoked by a light touch or air-puff, 9 points; recumbent position on deafferented side without leg support, 8 points; some ipsilesional leg support, 7 points; moving around on one side or using ipsilesional legs for recumbent support, 6 points; moving around with bilateral leg support, 5 points; moving around with occasional falls to the ipsilesional side, 4 points; moving around leaning toward the ipsilesional side, 3 points; hardly noticeable asymmetry, 2 points; postural asymmetry only noticeable when picked up, 1 point.

Head roll tilt scoring. Spontaneous head roll tilt was scored by measuring the angle between the jaw plane and the horizontal (Bergquist et al., 2008; Günther et al., 2015). 10 points were given either for a $90^{\circ}$ angle or if the animal rested recumbent on the lesion side or showed barrel-rolling toward that side. 7 points were correlated with a $60^{\circ}$ and 5 points with a $40^{\circ}$ angle.

Spontaneous nystagmus scoring. Spontaneous nystagmus was recorded using a video eye-tracking system for rodents (ETL-200, ISCAN; Dyhrfjeld-Johnsen et al., 2013; Jiang and Rajguru, 2018). Spontaneous nystagmus with fast phase was scored with $6-10$ points, with 1 point for every 60 beats per minute (bpm; Bergquist et al., 2008; Günther et al., 2015). When spontaneous nystagmus disappears at rest, the rats were given a gentle air-puff over the head. Evoked nystagmus was scored 1-5 points, with 1 point for every $60 \mathrm{bpm}$.

Open-field test. Rats were tested in an open field $(50 \times 50 \times 40 \mathrm{~cm})$ lit with a $60 \mathrm{~W}$ bulb above the field with no interference noise or any other jamming. After placing a rat at the center of the arena, locomotor activity was recorded for $10 \mathrm{~min}$ by a video camera. Head orientation during locomotion was evaluated by measuring the angle between the jaw plane and the horizontal of the tested rats in screenshots captured every $5 \mathrm{~s}$ from the video. Locomotor distance and body movement velocity were analyzed by Clever TopScan Software (CleverSys).

Rotarod test. Each rat was placed in an individual compartment of the rotarod (7750, Ugo Basile) and was required to keep constant walking to avoid falling off the rod. Rats were first acclimated on the rod rotating at 4 revolutions per minute (rpm) for $30 \mathrm{~s}$, and then the rod was evenly accelerated up to $40 \mathrm{rpm}$ during $180 \mathrm{~s}$. Latency for rat to fall from the rotating rod was recorded, and the time beyond $180 \mathrm{~s}$ was recorded as $180 \mathrm{~s}$. For the test, each rat was subjected three trials, with a resting interval of 3 min to relieve stress and fatigue.

Negative geotaxis test. This test is considered as a diagnostic of vestibular function, reflex development, and motor skills (Altman and Sudarshan, 1975; J. Zhang et al., 2011). Rats were placed on a $40^{\circ}$ incline with their head pointing down the slope, and the time spent for a turn of $180^{\circ}$ upward was recorded. The animals were allowed a $90 \mathrm{~s}$ rest between trials to reduce stress and fatigue.

\section{Histological identification}

On the last day of the behavioral tests, rats were deeply anesthetized with an overdose of sodium pentobarbital. Two insulated stainless steel wires (o.d.: $0.4 \mathrm{~mm}$ ) with $0.2 \mathrm{~mm}$ exposed tip were inserted into the MVN under guidance of guide tubes for depositing iron at the site of injection by passing DC current (10 $\mu \mathrm{A}, 20 \mathrm{~s})$. The brain was then removed and 
A
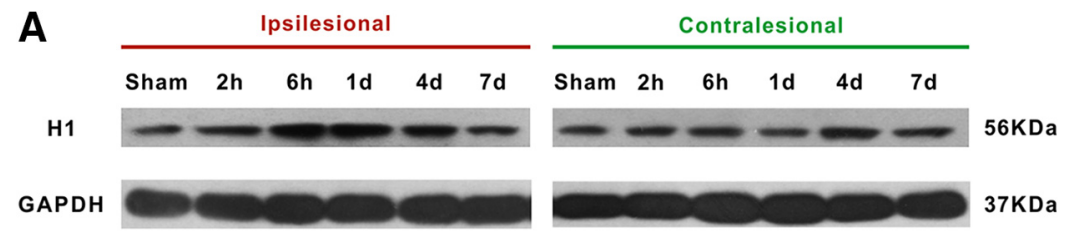

B

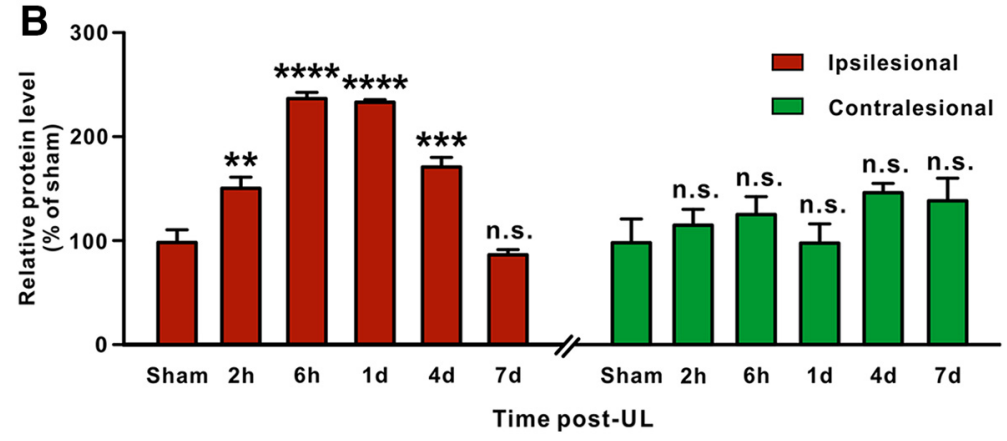

Figure 1. Western blot analyses of $\mathrm{H} 1$ receptor expression in the bilateral MVNs after UL. $\boldsymbol{A}$, Western blots of $\mathrm{H} 1$ receptor expression in the ipsilesional and contralesional MVN after UL and sham operation. $\boldsymbol{B}$, Semiquantitative densitometric analysis of $\mathrm{H} 1$ receptor expression in Western blots. $\mathrm{H} 1$ receptor expression in the ipsilesional and contralesional MVN in UL rats was normalized to that in MVN in the sham-operated rats. Data represent mean \pm SEM. ${ }^{* *} p<0.01,{ }^{* * *} p<0.001,{ }^{* * * *} p<0.0001$, n.s. no significant difference, by repeated-measures ANOVA followed by Bonferroni's test.

fixed with $4 \%$ paraformaldehyde containing $1 \%$ potassium ferrocyanide. A week later, frozen serial coronal sections ( $50 \mu \mathrm{m}$ thick) were prepared, performed with Nissl staining and the dark blue dots indicating injection sites were identified according to the rat brain atlas (Paxinos and Watson, 2014). Data from rats in which the injection sites were deviated from the MVN were excluded from further analysis.

Experimental design and statistical analysis

All experiments and data analysis were performed blind to the conditions of the experiments. In behavioral tests, animals were randomly grouped by different treatments. Sample sizes were based on the previous reports (Lacour, 2013; Günther et al., 2015). All data are presented as mean \pm SEM. Shapiro-Wilk test was used for testing the normality of data. The Student's $t$ test, one-way and repeated-measures two-way ANOVA, and Bonferroni's post hoc testing was used for statistical analysis. The critical level of statistical significance was $p<0.05$.

\section{Results}

$\mathrm{H} 1$ receptor expression is selectively increased in the ipsilesional MVN commissural GABAergic neurons after UL We first assessed the expression of $\mathrm{H} 1$ receptor protein in bilateral MVNs after UL by Western blotting. We found that the expression of $\mathrm{H} 1$ receptor was significantly increased in the ipsilesional rather than contralesional MVN at $2 \mathrm{~h}(n=8, p=$ $0.0033), 6 \mathrm{~h}(n=8, p<0.0001), 1 \mathrm{~d}(n=8, p<0.0001)$, and $4 \mathrm{~d}$ $(n=8, p=0.0002)$ post-UL, compared with the sham-operated group (Fig. 1). The increased expression of $\mathrm{H} 1$ receptor in the ipsilesional MVN returned to baseline level at $7 \mathrm{~d}$ post-UL $(n=8$, $p>0.9999$; Fig. 1). Thus, we speculate that the selective increase in $\mathrm{H} 1$ receptor expression in the ipsilesional MVN may be closely related to the recovery of largely asymmetric activity between bilateral MVNs.

We further mapped the distribution of $\mathrm{H} 1$ receptor in the ipsilesional MVN in UL rats by immunostaining. Since vestibular commissural inhibitory system has been strongly implicated both in the initial vestibular symptoms after UL and in the subsequent functional recovery (Gliddon et al., 2005), we used retrograde tracing combined with immunostaining to dissect the expression of $\mathrm{H} 1$ receptor in the GABAergic projection neurons of the commissural inhibitory system. In sham-operated rats $(n=5)$, retro- gradely labeled GAD67-immunoreactive neurons in the MVN have strong $\mathrm{H} 1$ receptor immunoreactivity (Fig. 2-1, available at https://doi.org/10.1523/JNEUROSCI.135018.2018.f2-1), indicating H1 receptor is expressed in the GABAergic neurons projecting to the contralateral MVN, i.e., the vestibular commissural inhibitory neurons. Therefore, we microinjected retrograde tracer FG into the contralesional or ipsilesional MVN in rats $(n=5$ and 6, respectively) 3 weeks before UL, and observed the expression of $\mathrm{H} 1$ receptor in the retrogradely labeled neurons in bilateral MVNs after UL (Fig. 2A,F). Consistent with the above Western bolt result, the distribution of $\mathrm{H} 1$ receptor in the ipsilesional rather than contralesional MVN increased at $1 \mathrm{~d}$ post-UL ( $p=0.0155$; Fig. $2 B-E, G-K$ and Fig. 2-1, available at https://doi.org/10.1523/JNEUROSCI. 1350-18.2018.f2-1). Interestingly, the labeling intensity of $\mathrm{H} 1$ receptors was significantly increased in the FG +/GAD67+ neurons $(p=0.0003)$ rather than $\mathrm{FG}+1$ GAD67- neurons $(p>0.9999)$ in the ipsilesional MVN of the UL rats (Fig. $2 \mathrm{~K}$ ). These immunostaining results suggest that the expression of $\mathrm{H} 1$ receptor may be selectively increased in the ipsilesional MVN commissural inhibitory GABAergic neurons after UL.

The excitation induced by $\mathrm{H} 1$ receptor activation is enhanced in the ipsilesional MVN commissural GABAergic neurons after UL

Given that rebalancing the commissural inhibitory system is critical for vestibular compensation (Gliddon et al., 2005) and above-mentioned histamine $\mathrm{H} 1$ receptor exhibited asymmetric increase in expression in the commissural inhibitory system after UL, we investigated the changes in responses of commissural inhibitory neurons in bilateral MVNs to histamine after UL by whole-cell patch-clamp recording in brainstem slices. As shown in Figure 3A, UL was conducted in rats microinjected with FG in the contralesional or ipsilesional MVN, and brainstem slices were prepared for whole-cell current-clamp recordings. The retrogradely labeled MVN neurons on the contralateral side of FG injection were targeted and identified as vestibular commissural neurons by viewing with brief epifluorescent illumination. The GABAergic and glutamatergic MVN commissural neurons recorded in this study were categorized by filling the recorded neurons with biocytin and immunostaining them for GAD67 or glutamate (Fig. $3 A, B, F$ ).

A total of $33 \mathrm{MVN}$ commissural neurons were identified and recorded in the present study. Among them, GABAergic MVN commissural neurons $(n=17)$ showed significantly smaller ADP and wider action potential half-width than glutamatergic ones ( $n=16$; Fig. 3-1A, $B$, available at https://doi.org/10.1523/ JNEUROSCI.1350-18.2018.f3-1), which is in accordance with previous reports (Bagnall et al., 2007). The effect of H1 receptor activation was isolated by administration of histamine in the presence of ranitidine and iodophenpropit, selective antagonists for $\mathrm{H} 2$ and $\mathrm{H} 3$ receptors, respectively. We found that activation of $\mathrm{H} 1$ receptor induced a homogeneous excitation in a concentration-dependent manner on both ipsilesional and contral- 
A

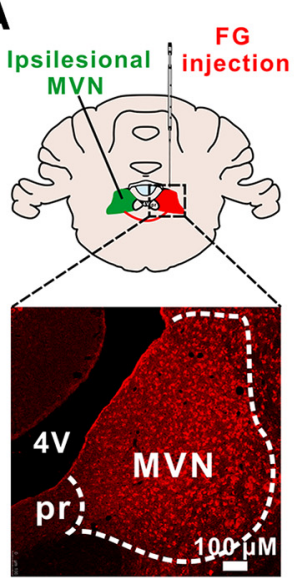

F

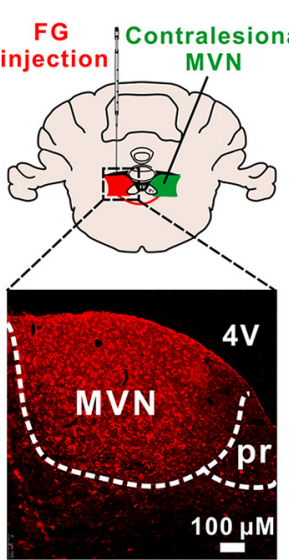

B
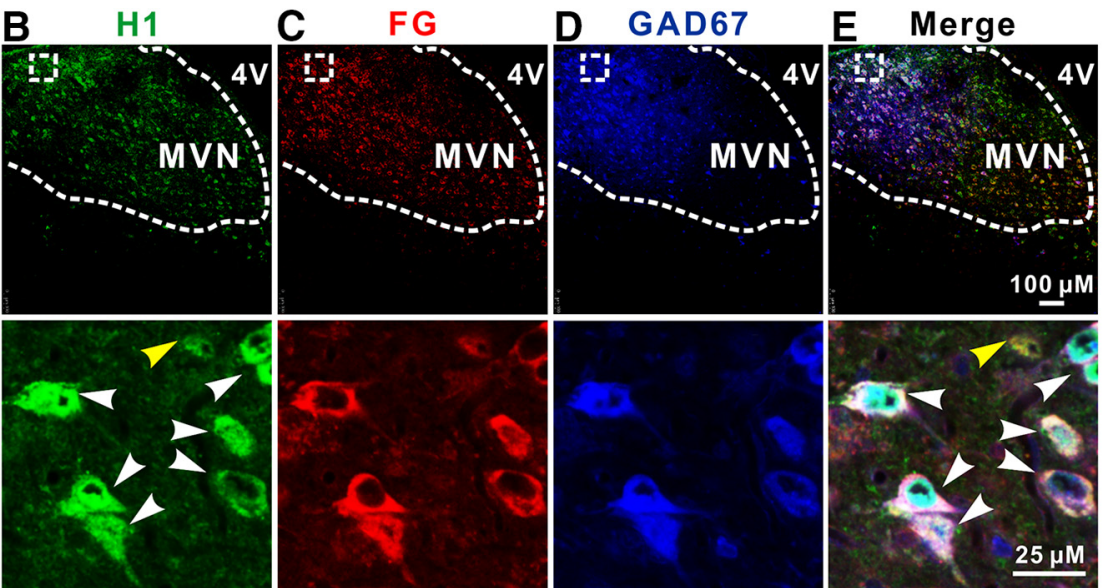

G
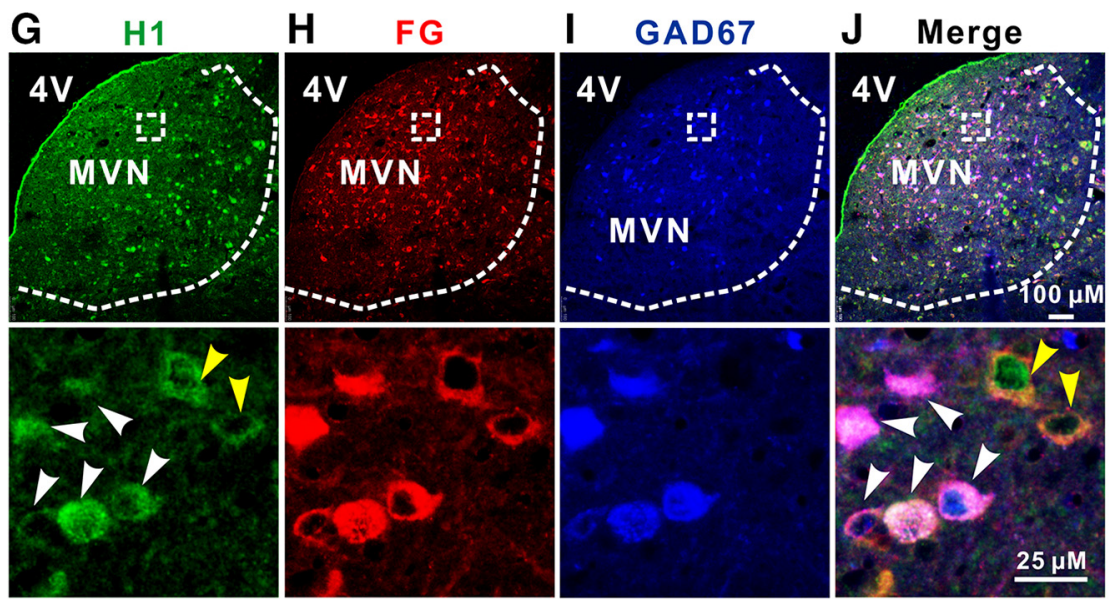

K

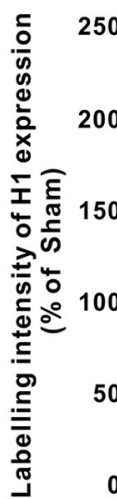

K
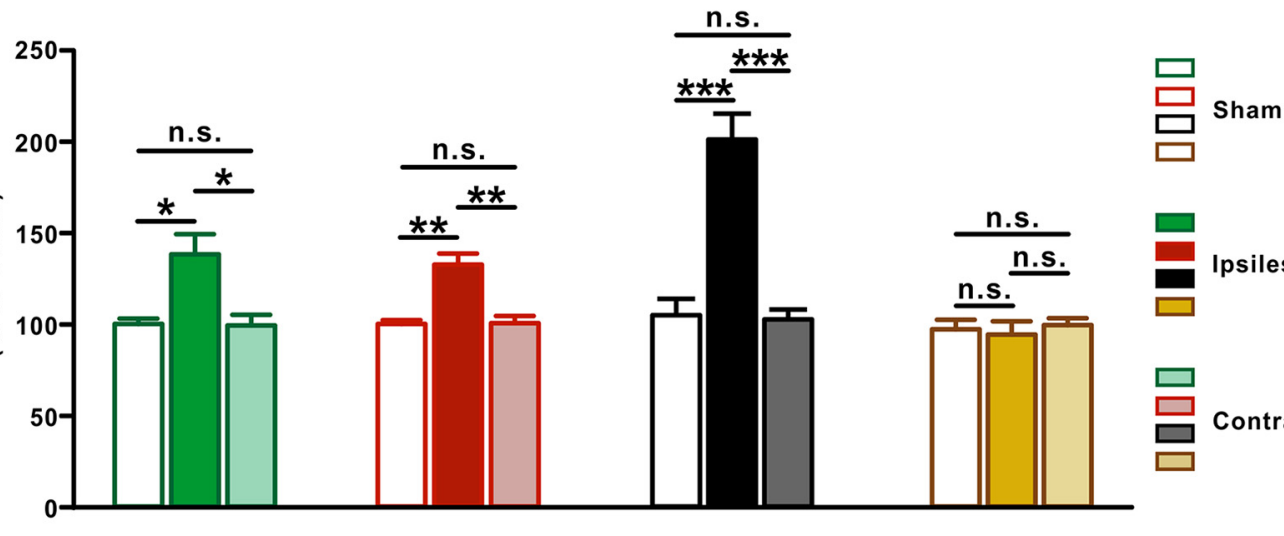

H1+

H1+/FG+

H1+/FG+/GAD67+ H1+/FG+/GAD67-

Figure 2. The expression of $\mathrm{H} 1$ receptor is selectively increased in the ipsilesional GABAergic MVN commissural neurons after UL. $A$, Diagram and a coronal brain section showing the injection site of $\mathrm{FG}$ in the contralesional MVN. $\boldsymbol{B}-\boldsymbol{E}$, Triple immunostainings for $\mathrm{H1}$ receptor (green; $\boldsymbol{B})$, $\mathrm{FG}(\mathrm{red} ; \boldsymbol{C})$ and GAD67 (blue; $\boldsymbol{D})$ in the ipsilesional MVN. White arrowheads in the merged image $(\boldsymbol{B}, \boldsymbol{E})$ indicate the $\mathrm{H1} / \mathrm{FG} / \mathrm{GAD} 67$ triple-labeled GABAergic MVN commissural neurons, whereas yellow arrowhead in the merged image $(\boldsymbol{B}, \boldsymbol{E})$ indicates $\mathrm{H1} / \mathrm{FG}$ doublelabeled non-GABAergic (glutamatergic) commissural neuron. $F$, Diagram and a coronal brain section showing the injection site of FG in the ipsilesional MVN. G-J, Triple immunostainings for $\mathrm{H1}$ receptor $(\boldsymbol{G}$, green), $\mathrm{FG}(\boldsymbol{H}$, red) and GAD67 ( $\boldsymbol{I}$, blue) in the contralesional MVN. White arrowheads in the merged image $(\boldsymbol{G}, \boldsymbol{J})$ indicate the H1/FG/GAD67 triple-labeled GABAergic MVN commissural neurons, whereas yellow arrowheads in the merged image $(G, J)$ indicate H1/FG double-labeled non-GABAergic (glutamatergic) commissural neurons. $\boldsymbol{K}$, Labeling intensity of $\mathrm{H} 1$ receptor expression in the $\mathrm{H} 1+, \mathrm{FG}+, \mathrm{FG}+/ \mathrm{GAD} 67+$, and $\mathrm{FG}+/ \mathrm{GAD} 67$ - neurons in the MVN in sham rats and the ipsilesional and contralesional MVNs in UL rats. Data represent mean \pm SEM. ${ }^{*} p<0.05,{ }^{* *} p<0.01,{ }^{* * *} p<0.01$, n.s. no significant difference, by two-way ANOVA followed by Bonferroni's test. See also Figure $2-1$, available at https://doi.org/10.1523/JNEUROSCI.1350-18.2018.f2-1.

esional MVN commissural neurons (Fig. 3 and Fig. 3-1, available at https://doi.org/10.1523/JNEUROSCI.1350-18.2018.f3-1), which is consistent with our previous study on $\mathrm{H} 1$ receptormediated postsynaptic excitation on MVN neurons in normal rats (X. Y. Zhang et al., 2013). Notably, the concentrationdependent firing rate enhancement induced by $\mathrm{H} 1$ receptor activation in the recorded ipsilesional MVN GABAergic projection neurons $(n=8)$ of the commissural inhibitory system were 


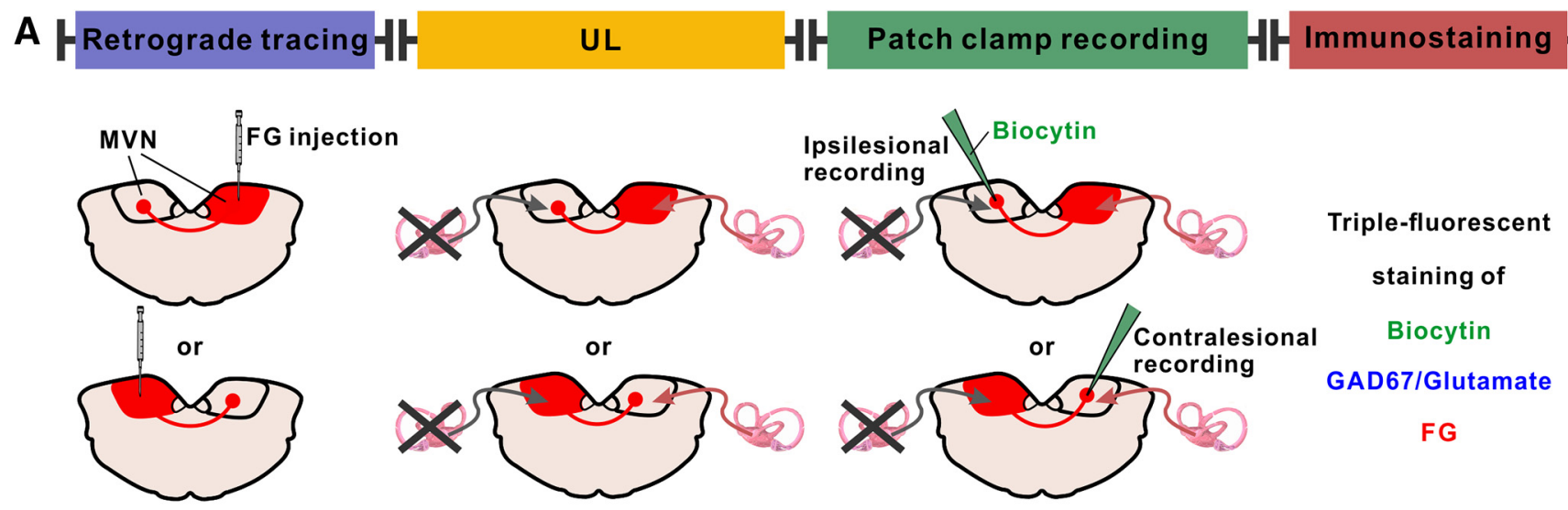

\section{GABA commissural neuron}
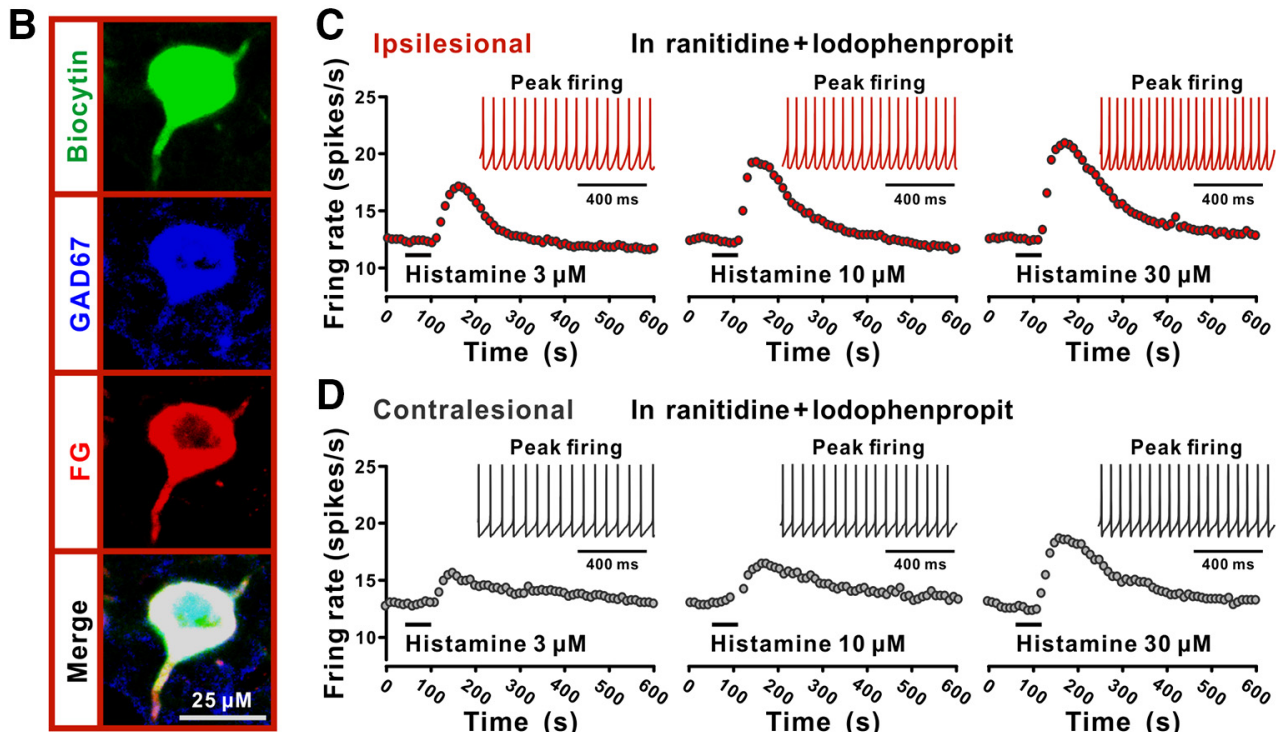

D Contralesional In ranitidine+lodophenpropit
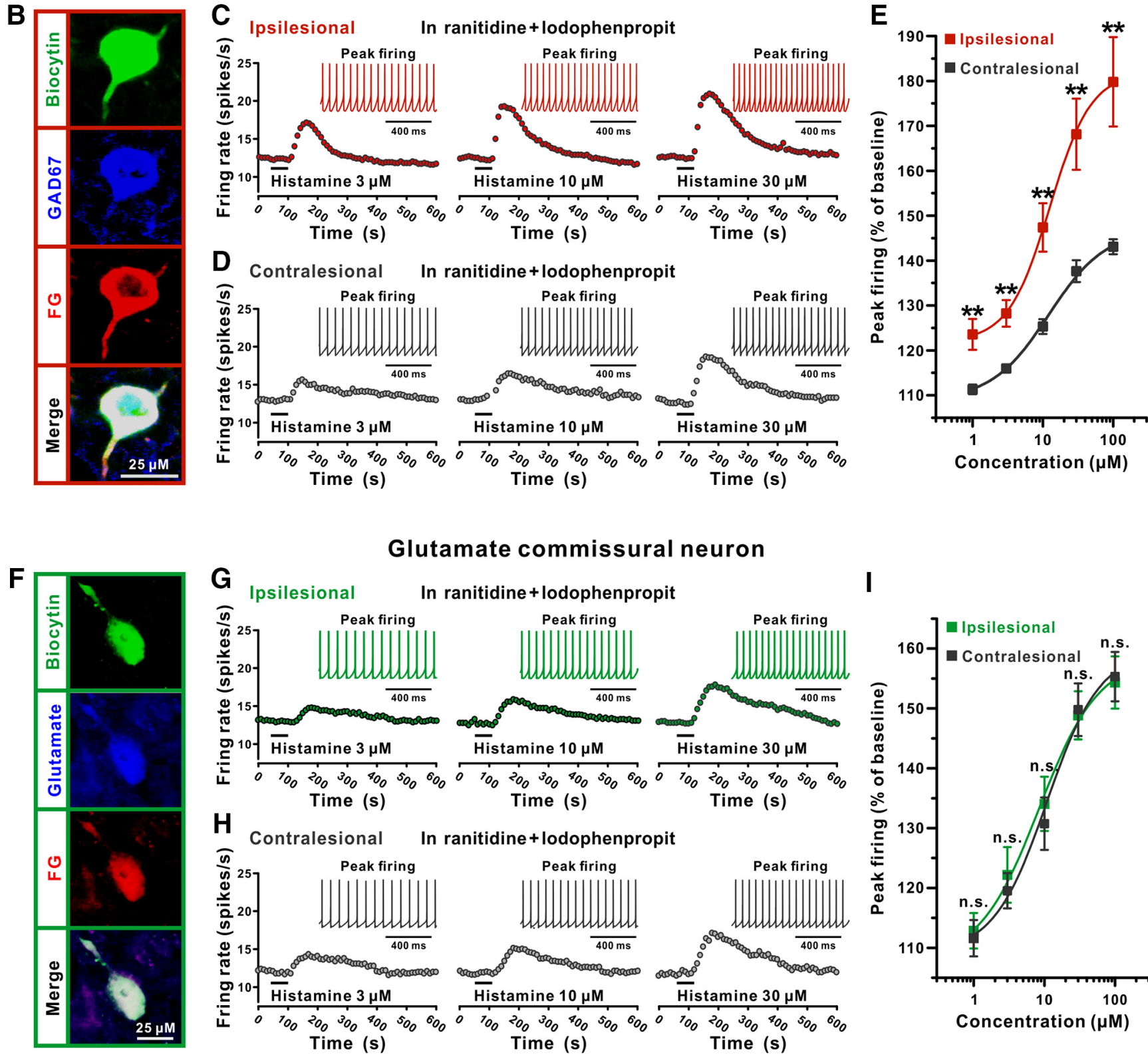

\section{I}

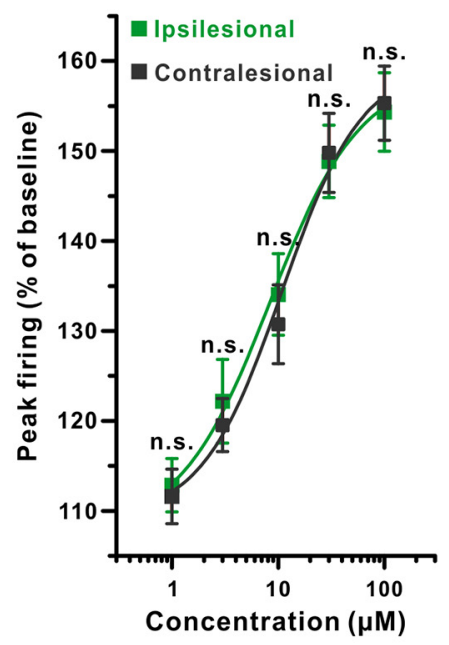

Figure 3. The excitation induced by H1 receptor activation is enhanced in the ipsilesional MVN GABAergic projection neurons of the commissural inhibitory system after UL. A, Schematic representation of experimental design. $\boldsymbol{B}$, Identification of the GABAergic MVN commissural neurons recorded in brain slices. The retrogradely labeled MVN neurons on the contralateral side of FG injection were current-clamped and injected with biocytin. The recorded neurons with triple immunopositive for biocytin (green), GAD67 (blue), and FG (red) were identified as the GABAergic commissural inhibitory neurons. C, D, PSTHs show that activation of $\mathrm{H} 1$ receptor by application of histamine in the presence of ranitidine (H2 receptor antagonist) (Figure legend continues.) 
A

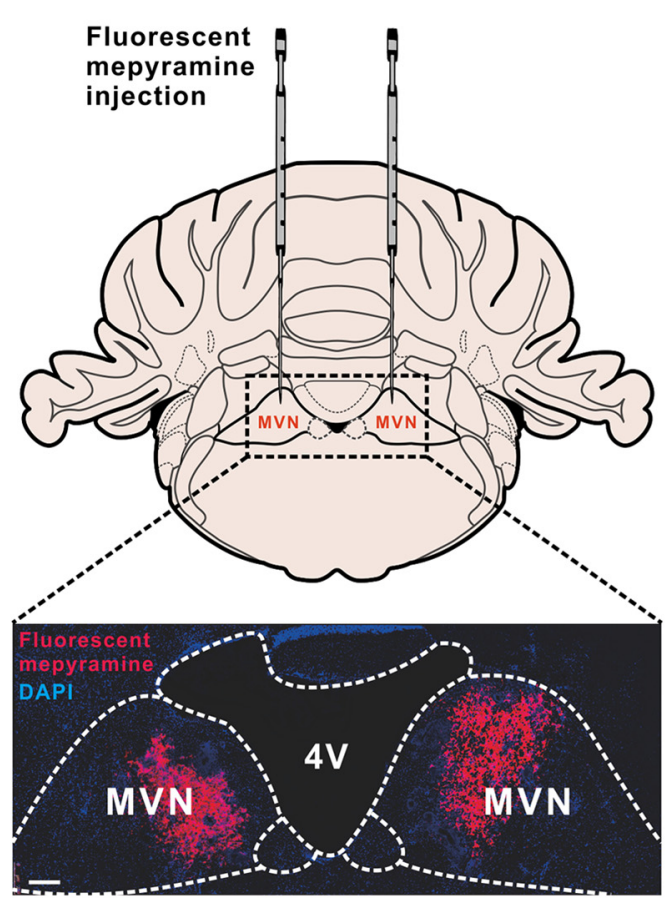

B

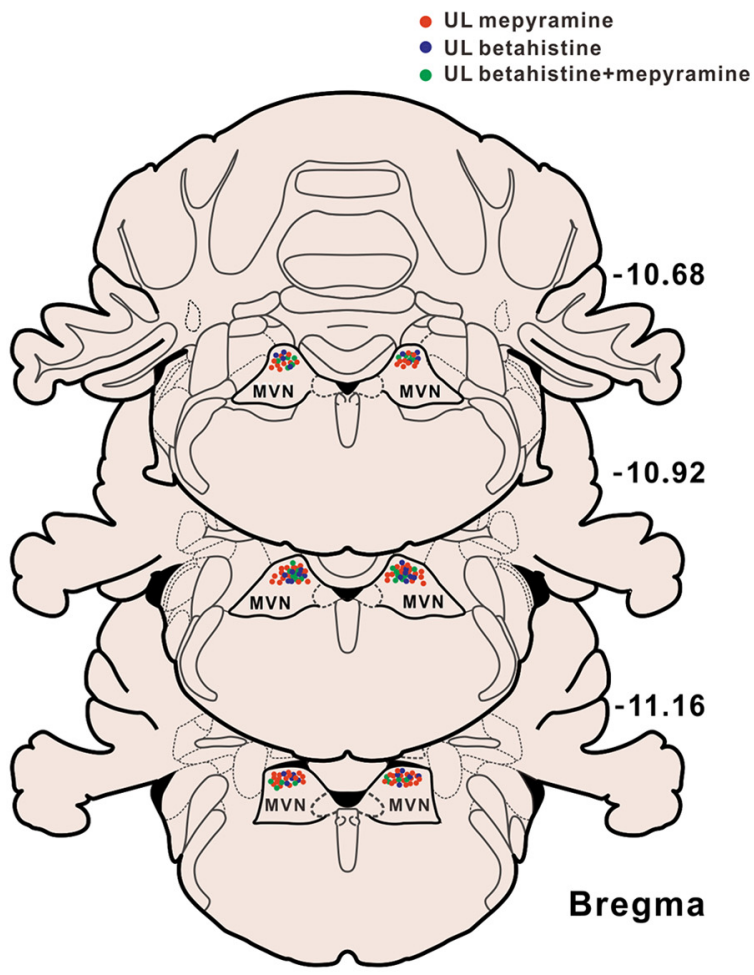

Figure 4. Histological identification of the spread of mepyramine and the locations of microinjection sites in bilateral MVNs. $A$, Confocal image of a coronal brain section of rats microinjected with fluorescent mepyramine showing the spread of fluorescent mepyramine (red) in MVNs labeled by DAPI (blue). $\boldsymbol{B}$, Histological reconstructions showing the microinjecting sites of mepyramine in MVNs in 42 rats.

significantly larger than those in the contralesional GABAergic commissural neurons $(n=9$; Fig. $3 C, D$, and Fig. 3-1C, $D$, available at https://doi.org/10.1523/JNEUROSCI.1350-18.2018.f3-1), indicated by an upward shift in the histamine concentrationresponse curve (Fig. 3E). On the other hand, there were no significant differences between the histamine-induced excitations mediated by $\mathrm{H} 1$ receptor in the recorded ipsilesional MVN glutamatergic projection neurons of the commissural excitatory system $(n=7)$ and those in the contralesional glutamatergic commissural neurons ( $n=9$; Fig. $3 G-I$, and Fig. 3-1E, F, available at https://doi.org/10.1523/JNEUROSCI.1350-18.2018.f3-1). These results strongly suggest that the responsiveness of the ipsilesional MVN commissural inhibitory rather than excitatory neurons to histamine may be selectively increased after UL to rebalance the excitability of bilateral MVNs, which coincides with

$\leftarrow$

(Figure legend continued.) and iodophenpropit ( $\mathrm{H3}$ receptor antagonist) induced a concentration-dependent excitation on the ipsilesional ( $\boldsymbol{C}$ ) and contralesional (D) GABAergic MVN commissural neurons with different amplitudes. The inset of each PSTH represents the raw data of peak firing. $\boldsymbol{E}$, Concentration-response curves for histamine in the presence of ranitidine and iodophenpropit on the recorded ipsilesional (red) and contralesional (black) GABAergic MVN commissural neurons. $\boldsymbol{F}$, Identification of the glutamatergic MVN commissural neurons recorded in brain slices. The recorded neurons with triple immunopositive for biocytin (green), glutamate (blue), and FG (red) were identified as the glutamatergic commissural excitatory neurons $(\boldsymbol{F}) . \boldsymbol{G}, \boldsymbol{H}, \mathrm{PSTH}$ s show that activation of $\mathrm{H} 1$ receptor by application of histamine in the presence of ranitidine and iodophenpropit induced a concentration-dependent excitation on the ipsilesional $(\boldsymbol{G})$ and contralesional $(\boldsymbol{H})$ glutamatergic MVN commissural neurons with similar amplitudes. The inset of each PSTH represents the raw data of peak firing. $I$, Concentrationresponse curves for histamine in the presence of ranitidine and iodophenpropit on the recorded ipsilesional (green) and contralesional (black) glutaminergic MVN commissural neurons. Data represent mean \pm SEM. ${ }^{* *} p<0.01$, n.s. no significant difference, by two-tailed unpaired $t$ test. See also Figure 3-1, available at https://doi.org/10.1523/JNEUROSCI.1350-18.2018.f3-1. the increase in $\mathrm{H} 1$ receptor expression in the ipsilesional commissural inhibitory neurons.

\section{H1 receptor antagonists retard vestibular compensation for static symptoms after UL}

Considering $\mathrm{H} 1$ receptor-mediated asymmetric excitation of the commissural GABAergic neurons in the ipsilesional MVN may help to rebalance bilateral vestibular systems and promote vestibular compensation, we further determined whether $\mathrm{H} 1$ receptor contributed to the recovery of vestibular syndromes after UL. Consistent with the previous reports (Bergquist et al., 2008; Günther et al., 2015), all animals exhibited typical static symptoms of vestibular dysfunction following UL, including posture asymmetry, head tilt, and nystagmus. In addition, the fast phase of spontaneous nystagmus we recorded was directed toward the intact side, which fits nicely with the inhibitory and excitatory connections from the MVN to the oculomotor nuclei (Wentzel et al., 1995). We used selective histamine $\mathrm{H} 1$ receptor antagonists, diphenhydramine, and mepyramine, to evaluate the contribution of postsynaptic $\mathrm{H} 1$ receptor to the recovery of the static symptoms. To identify the microinjection sites and diffusion extent of microinjected drugs, the spread of fluorescent mepyramine in the MVN was detected (Fig. 4A) and the histologically verified injection sites in bilateral MVNs were reconstructed $(n=$ 42 in each side; Fig. 4B). Diphenhydramine (i.p.), a commonly used antihistamine, significantly increased the scores of static postural asymmetry ( $6 \mathrm{~h}$ post-UL), head tilt (lasting from 6 to $24 \mathrm{~h}$ post-UL), nystagmus (lasting from 6 to $24 \mathrm{~h}$ post-UL), and the overall scores for static symptoms (lasting from 5 to $24 \mathrm{~h}$ post-UL; $n=14$; Fig. 5-1, available at https://doi.org/10.1523/ JNEUROSCI.1350-18.2018.f5-1). Similarly, mepyramine, locally microinjected into the bilateral MVNs, remarkably interfered 
A

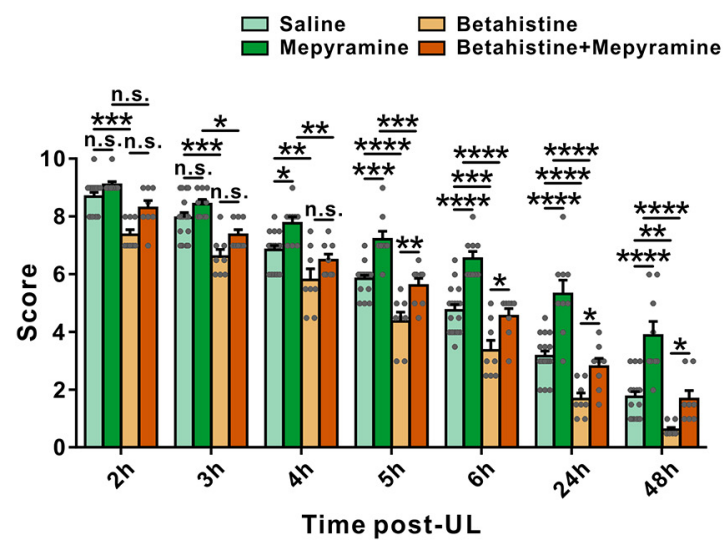

C

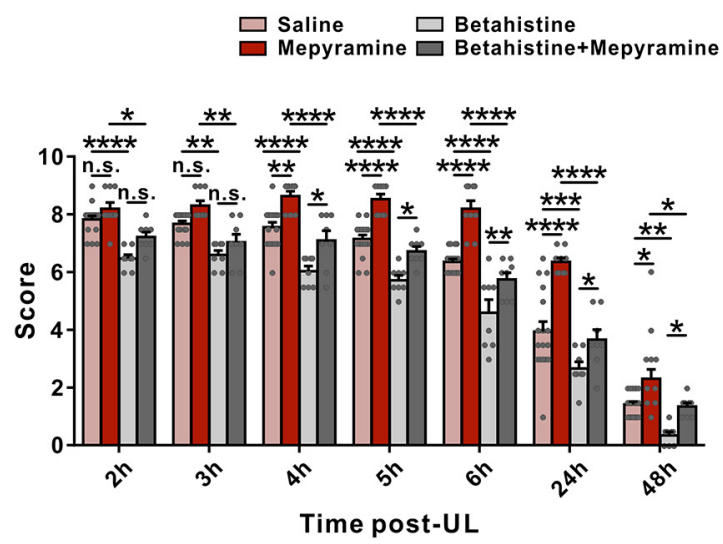

B

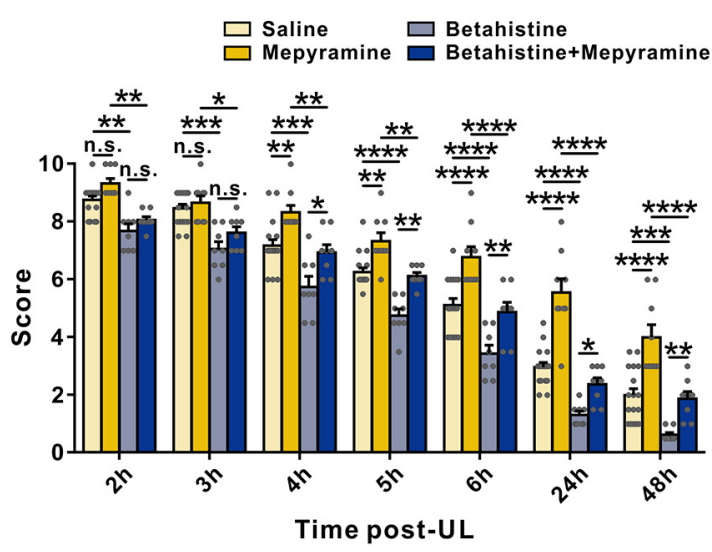

D

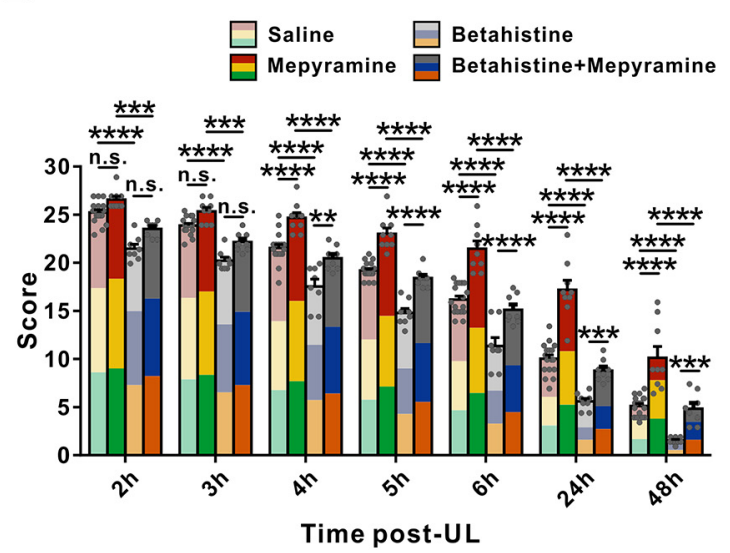

Figure 5. Microinjection of histamine $\mathrm{H} 1$ receptor antagonist mepyramine into MVN aggravates static symptoms and attenuates the betahistine-induced facilitation of static symptoms recovery in UL rats. $\boldsymbol{A}-\boldsymbol{C}$, Histograms illustrating the time course of recovery from posture asymmetry $(\boldsymbol{A})$, head tilt $(\boldsymbol{B})$, and nystagmus $(\boldsymbol{C})$ in four groups microinjected with mepyramine, betahistine, betahistine together with mepyramine, and saline, respectively. $\boldsymbol{D}$, Histogram showing the time course of overall performance of four groups microinjected with mepyramine, betahistine, betahistine together with mepyramine, and saline, respectively. Data shown are means \pm SEM. ${ }^{*} p<0.05,{ }^{* *} p<0.01,{ }^{* * *} p<0.001,{ }^{* * * *} p<0.0001$, n.s. no significant difference, by repeated-measures ANOVA followed by Bonferroni's test. See also Figure 5-1, available at https://doi.org/10.1523/JNEUROSCI.1350-18.2018.f5-1.

with the recovery of postural asymmetry, head tilt, nystagmus, and the overall static symptoms from 4 to 48 host-UL $(n=9$; Fig. 5). These results strongly suggest that histamine $\mathrm{H} 1$ receptor in the MVN may actively participate in the recovery of static symptoms after UL.

Given that betahistine has long been used in the treatment of vestibular disorders (Tighilet et al., 2005; Chazot, 2013; Lacour, 2013) and mainly been focused on its H3-antagonistic effect (Tighilet et al., 2007), we next examined whether the weak H1agonistic effect of betahistine was involved in its therapeutic effect on vestibular compensation. As shown in Figure 5, bilateral microinjection of betahistine into MVNs significantly facilitated the recovery of postural asymmetry, head tilt, nystagmus and the overall static symptoms from 2 to 48 h post-UL $(n=8)$. Moreover, microinjection of betahistine together with mepyramine into bilateral MVNs not only remarkably attenuated the facilitation of betahistine on the recovery of postural asymmetry, head tilt, and nystagmus (Fig. 5), but also alleviated the retardation of mepyramine on the recovery of static vestibular symptoms (Fig. 5), suggesting that $\mathrm{H} 1$ receptor may also be responsible for the potential therapeutic effect of betahistine for vestibular compensation.
H1 receptor antagonists retard vestibular compensation for dynamic dysfunction in locomotion and motor coordination after UL

We further assessed the role of histamine $\mathrm{H} 1$ receptor in the recovery of dynamic symptoms, the deficits in vestibular reflex responses to head movement. It has been well known that unilateral vestibular neurotomy patients exhibit impairments in locomotor parameters, for instance locomotor trajectory (Borel et al., 2004). Likewise, UL affected spontaneous locomotor activities and the steering of locomotion in rats (Fig. 6). Compared with the sham-operated group, locomotor distance $(n=8, p=$ 0.0176 ; Fig. $6 A, B, D)$ and velocity $(n=8, p=0.0460$; Fig. $6 A, B, E)$ of UL rats microinjected with saline into the MVN significantly decreased on the Day 1 post-lesion and recovered on the Day 4. Moreover, by analyzing relationship between head direction and locomotor velocity, we found that UL rats showed a slight deviation of head orientation (represented by the population vector) toward the ipsilesional side during locomotion $(n=8, p=0.0477$; Fig. $6 A, B, F)$. Notably, microinjection of mepyramine into the bilateral MVNs markedly decreased both the travel distance $(n=8, p<0.0001$; Fig. $6 C, D)$ and locomotor velocity $(n=8, p=0.0002$; Fig. $6 C, E)$ of UL rats. In addition, 
A

\section{Sham saline}

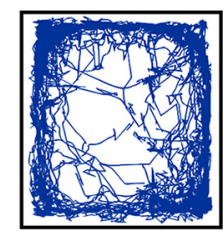

Locomotor trajectory

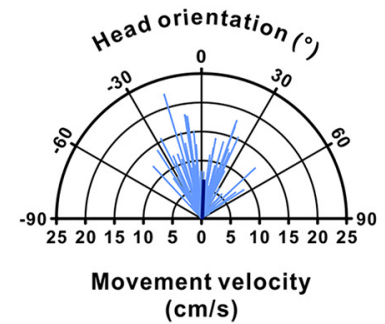

B

UL saline

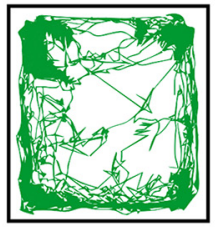

Locomotor trajectory

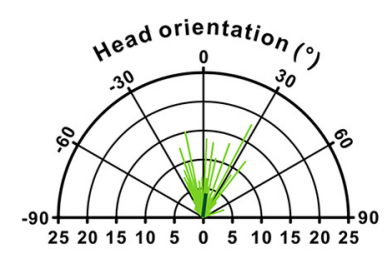

Movement velocity $(\mathrm{cm} / \mathrm{s})$
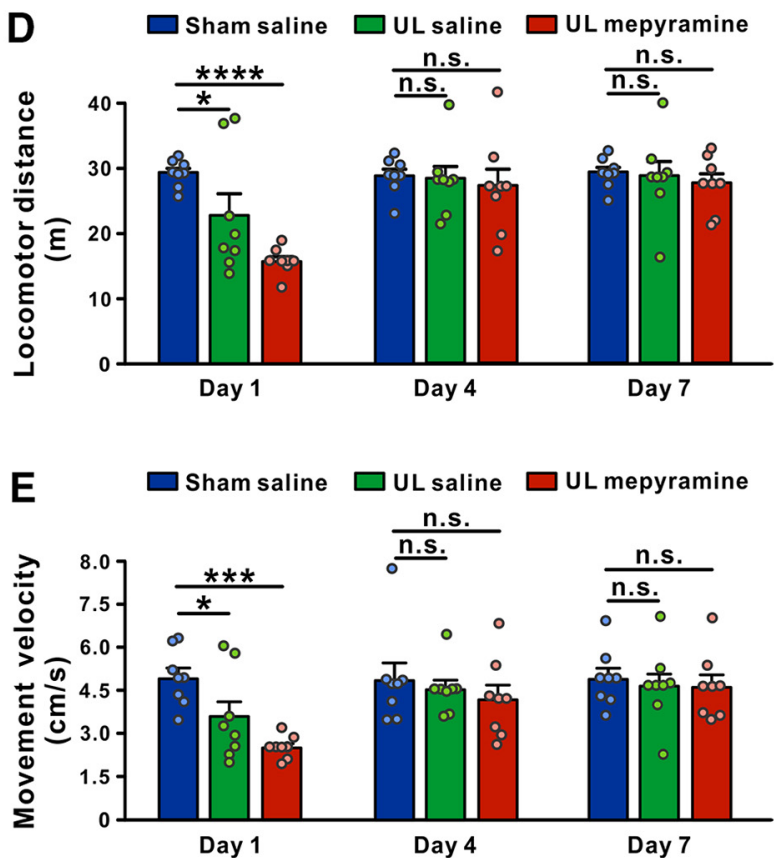

C UL mepyramine

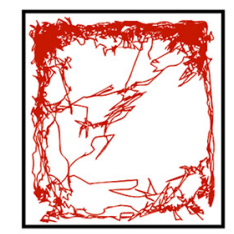

Locomotor trajectory
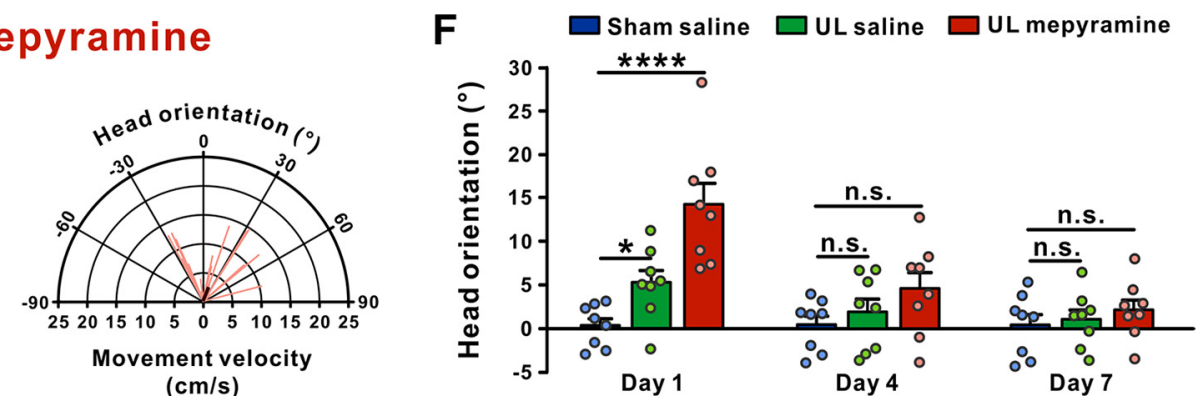

Figure 6. Microinjection of mepyramine into MVN aggravates locomotor dysfunction in UL rats. A-C, Locomotor trajectories (left) and polar coordinates (instantaneous body movement velocity vs instantaneous head orientation; right) of the sham group microinjected with saline (blue), the UL group microinjected with saline (green), and the UL group microinjected with mepyramine (red) in an open field on Day 1 postsurgery. $\boldsymbol{D}-\boldsymbol{F}$, Histograms illustrating the time course of the recovery of locomotor distance $(\boldsymbol{D})$, body movement velocity $(\boldsymbol{E})$, and head orientation $(\boldsymbol{F})$ in the sham group microinjected with saline (blue), the UL group microinjected with saline (green), and the UL group microinjected with mepyramine (red). Data represent mean \pm SEM. ${ }^{*} p<0.05,{ }^{* * *} p<0.001$, ${ }^{* * * *} p<0.0001$, n.s. no significant difference, by repeated-measures ANOVA followed by Bonferroni's test.

mepyramine significantly aggravated the deviation of head orientation during locomotion in UL rats $(n=8, p<0.0001$; Fig. $6 C, F)$. These results indicate that histamine $\mathrm{H} 1$ receptor is also involved in the recovery of locomotor deficits after UL.

Unlike static symptoms presenting with the head stationary show very fast and almost complete recovery, many dynamic dysfunctions accompanying head movements are usually compensated slowly (Curthoys, 2000; Darlington and Smith, 2000). Therefore, we determined the function of $\mathrm{H} 1$ receptor in the recovery of motor balance and coordination in UL rats by rotarod test. As shown in Figure 7 and Fig. 7-1 (available at https:// doi.org/10.1523/JNEUROSCI.1350-18.2018.f7-1) UL induced a significant dysfunction in motor balance and coordination $(n=$ 8 and 7, respectively), which persisted for $5 \mathrm{~d}$ postlesion. Furthermore, both mepyramine (microinjected in MVN; Fig. 7) and diphenhydramine (i.p.; Fig. 7-1, available at https://doi.org/ 10.1523/JNEUROSCI.1350-18.2018.f7-1) remarkably shortened the endurance time of UL rats ( $n=8$ and 7 , respectively) on the accelerating rotarod and extended the recovery period to 6 and $7 \mathrm{~d}$ postlesion, respectively. Mepyramine slowed down the betahistine-induced facilitation of recovery of dynamic vestibular dysfunction ( $n=9$; Fig. 7 ). All these results clearly suggest that histamine $\mathrm{H} 1$ receptor may greatly contribute to not only the fast compensation of static postural symptoms but also the slow recovery of dynamic motor deficits.

H1 receptor antagonist does not alter baseline vestibular motor functions in normal rats

To clarify whether histamine $\mathrm{H} 1$ receptor is specifically involved in postlesional recovery or also during baseline motor performance, we evaluated the effect of mepyramine on the behaviors of normal rats in the open field and negative geotaxis. As shown in Figure 8, microinjection of mepyramine into the bilateral MVNs had no effect on the travel distance $(n=9, p=0.2236$; Fig. $8 A)$, locomotor velocity $(n=9, p=0.7790$; Fig. $8 B)$ and head orientation $(n=9, p=0.9601$; Fig. $8 C)$ of normal rats in the open field. Moreover, in the negative geotaxis tests on a $40^{\circ}$ incline, bilateral microinjection of mepyramine into the MVN did not alter the time necessary to turn to $180^{\circ}$ upward from an initial position with animals' heads facing downward $(n=10, p>$ 0.9999; Fig. $8 D$ ). These results indicate that the symmetrically expressed histamine $\mathrm{H} 1$ receptor in the bilateral MVNs may not be directly involved in the baseline vestibular motor functions 


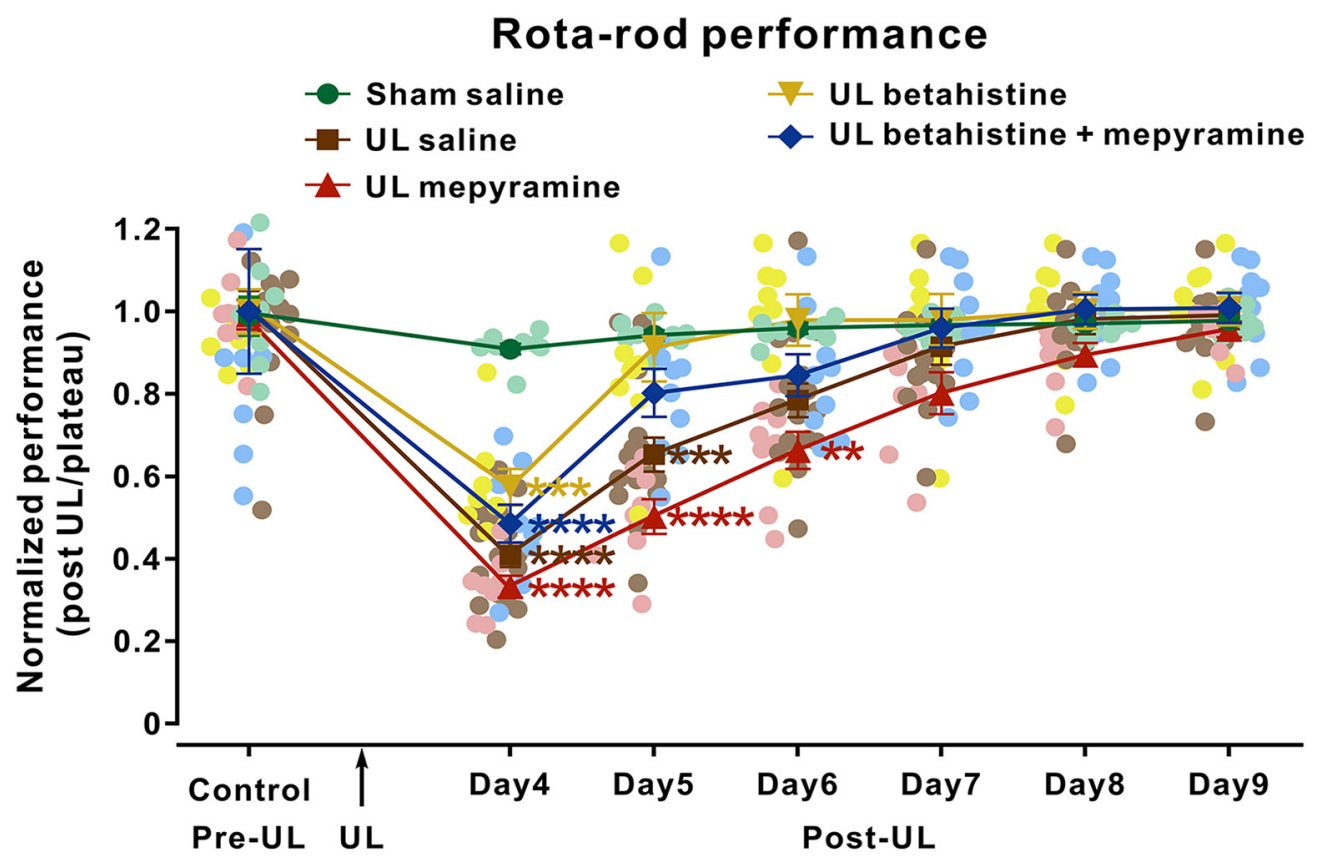

Figure 7. Microinjection of mepyramine into MVN retards recovery of motor balance and coordination in UL rats. Rats were trained consecutively on a rotarod for $4 \mathrm{~d}$ pre-UL. The test began on Day 4 post-UL. Curves illustrating the time course of the recovery of motor balance and coordination in rotarod test after UL in the sham group microinjected with saline (green dots), the UL group microinjected with saline (brown squares), the UL group microinjected with mepyramine (red right triangles), the UL group microinjected with betahistine (yellow inverted triangles), and the UL group microinjected with betahistine together with mepyramine (blue diamonds). Data represent mean \pm SEM. ${ }^{* *} p<0.01$, ${ }^{* *} p<0.001$, ${ }^{* * *} p<0.0001$, by repeated-measures ANOVA followed by Bonferroni's test. See also Figure 7-1, available at https://doi.org/10.1523/JNEUROSCI.1350-18.2018.f7-1.

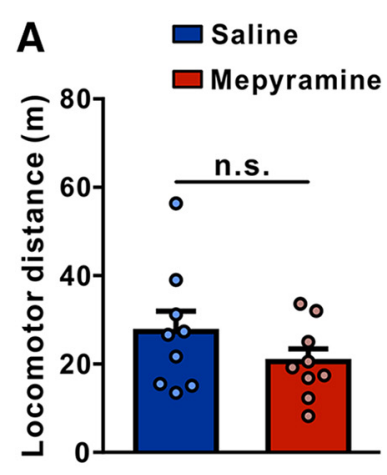

\section{Open-field}
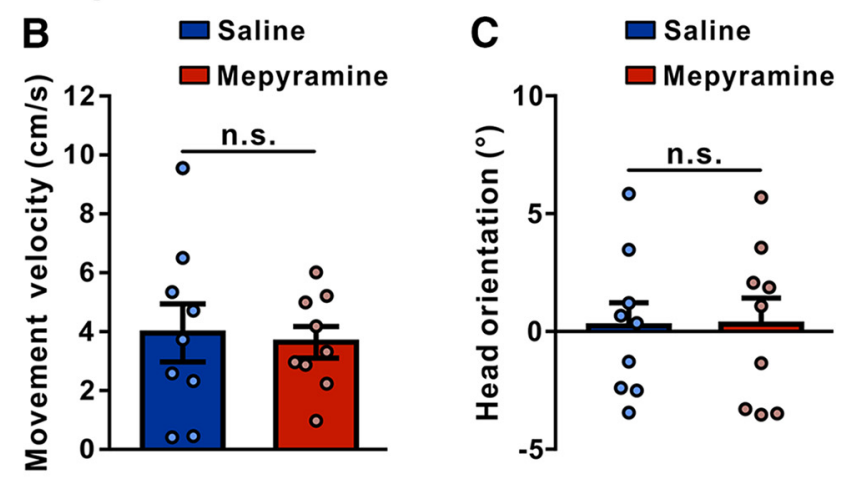

D

\section{Negative Geotaxis}

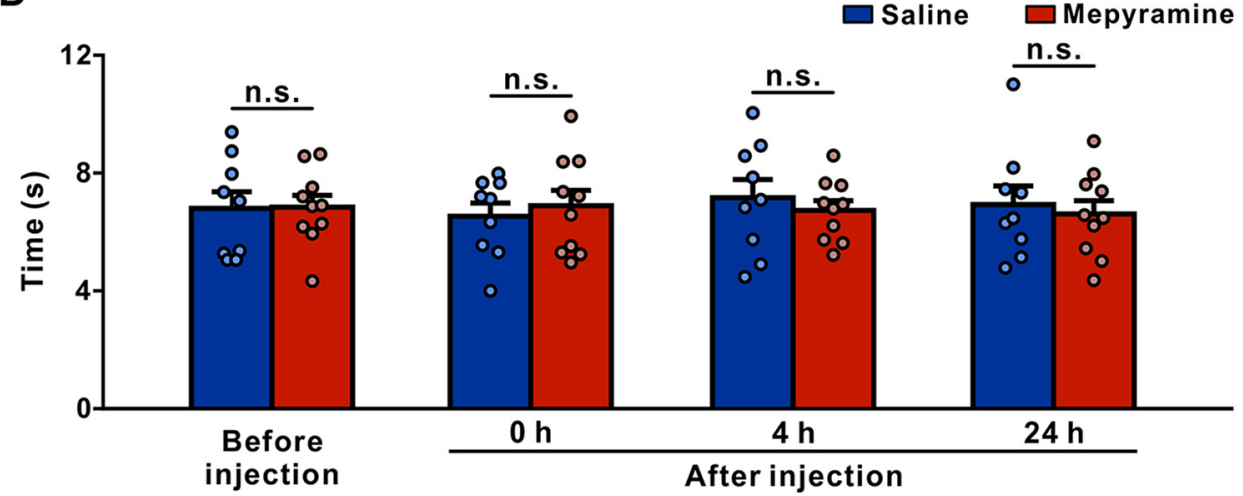

Figure 8. Microinjection of mepyramine into bilateral MVNs does not influence locomotion and negative geotaxis in normal rats. $\boldsymbol{A}-\boldsymbol{C}$, The locomotor distance $(\boldsymbol{A})$, body movement velocity $(\boldsymbol{B})$, and head orientation $(\boldsymbol{C})$ of normal rats microinjected with saline (blue) or mepyramine (red) in the open field. $\boldsymbol{D}$, The time necessary to turn to $180^{\circ}$ upward from an initial position with animals' heads facing downward on the $40^{\circ}$ incline of normal rats microinjected with saline and mepyramine. Data represent mean \pm SEM. n.s., no significant difference, by two-tailed unpaired $t$ test ( $A-C$ ) and repeated-measures ANOVA followed by Bonferroni's test (D). 


\section{A Normal}

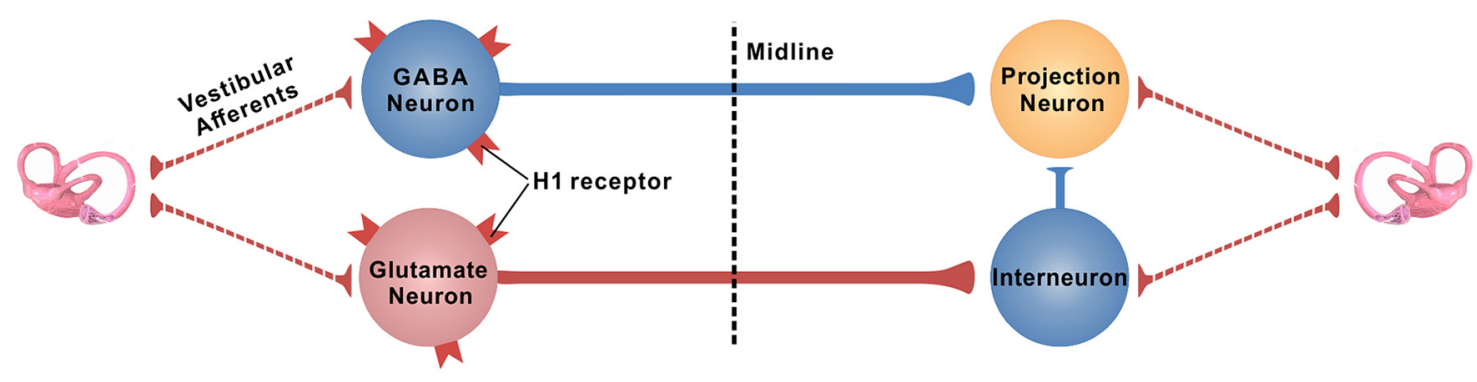

\section{B Compensation after UL}

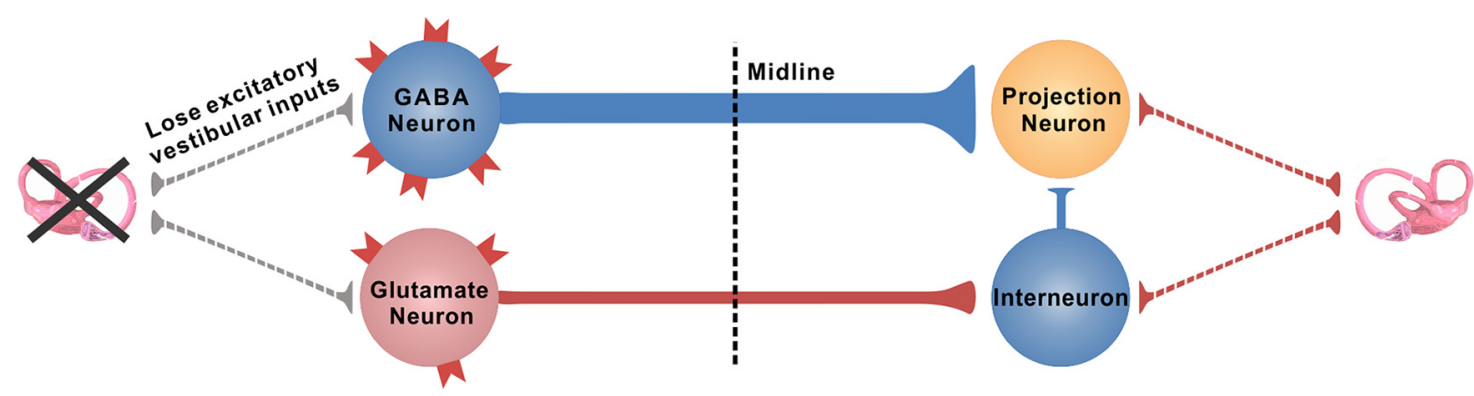

Figure 9. Schematic diagrams showing the role of histamine $\mathrm{H} 1$ receptor in vestibular compensation. $A$, In normal condition, neuronal activities between bilateral MVN neurons are in balance. $B$, After UL, the ipsilesional MVN neurons lose their excitatory drive from the lesioned primary vestibular afferents and therefore exhibit hypoactivity. The expression of $\mathrm{H} 1$ receptor is selectively increased in the ipsilesional GABAergic rather than glutamatergic MVN commissural neurons after UL. The $\mathrm{H} 1$ receptor-mediated enhancement of excitation on the ipsilesional GABAergic projection neurons of the commissural inhibitory system increases the inhibition on the contralesional MVN (GABAergic or glutamatergic) projection neurons to help to rebalance the activity of the bilateral MVNs and promote vestibular compensation.

but specifically contributes to the postlesional compensatory recovery.

\section{Discussion}

Vestibular compensation is responsible for spontaneous recovery of crude postural, locomotor, and oculomotor functions in patients with peripheral vestibular or posterior circulation abnormalities (Hoebeek et al., 2005; Chen et al., 2014; Kim and Zee, 2014; Brandt and Dieterich, 2017). Also, it is an attractive model for investigating lesion-induced plasticity in adult CNS (Straka et al., 2005; Gittis and du Lac, 2006; Lacour and Tighilet, 2010; Redon et al., 2011; Macdougall and Curthoys, 2012; Jamali et al., 2014; Zwergal et al., 2016). Here, we report for the first time, in functional perspective, that histamine postsynaptic $\mathrm{H} 1$ receptor holds a key position in vestibular pathophysiology and circuit plasticity in the commissural inhibitory system, and contributes to functional compensation for not only static postural dysfunctions but also dynamic motor deficits.

Histamine receptors, including $\mathrm{H} 1, \mathrm{H} 2$, as well as $\mathrm{H} 3$, are widely distributed throughout the MVN (Tighilet et al., 2005; Bergquist et al., 2006). The postsynaptic $\mathrm{H} 1$ and $\mathrm{H} 2$ receptors comediate the excitatory effect of histamine on MVN neurons (Yabe et al., 1993; Wang and Dutia, 1995; Peng et al., 2013; X. Y. Zhang et al., 2013; Zhuang et al., 2013), whereas the presynaptic $\mathrm{H} 3$ receptor serves as autoreceptor to inhibit histamine release and heteroreceptor to modulate GABA release (Tighilet et al., 2005; Bergquist et al., 2006). However, in clinic, only histamine $\mathrm{H} 1$ - and H3-receptor selective drugs have been widely used in the treatment of vestibular disorders (Chazot, 2009; Chihara et al.,
2013). Remarkably, betahistine, a $\mathrm{H} 3$ receptor antagonist and a weak $\mathrm{H} 1$ receptor agonist, has been clinically and experimentally shown to facilitate the functional recovery of vestibular functions (Lacour, 2013), which is distinct from most of the current vestibular pharmacotherapy that alleviates vertigo symptoms but fails to improve the natural compensation for vestibular damage (Strupp et al., 2015; Chabbert, 2016). In vestibular loss patients, betahistine treatment effectively reduces the recovery time for eye movements, head orientation as well as postural control after unilateral vestibular neurectomy, and thus significantly improves the quality of life (Mira, 2008; Redon et al., 2011; Lacour, 2013; Ramos Alcocer et al., 2015). Similarly, an acceleration of both static and dynamic recovery has been reported in cat models of unilateral vestibular loss under betahistine treatment (Lacour, 2013). The improvement of betahistine on vestibular compensation has long been owed to the presynaptic histamine $\mathrm{H} 3$ receptor. In the present study, we find that $\mathrm{H} 1$ receptor antagonists, diphenhydramine and mepyramine, retard vestibular compensation for both static symptoms, including static postural asymmetry, head tilt as well as nystagmus, and dynamic dysfunction in locomotion and motor coordination in UL rats. Moreover, the betahistine-induced facilitation of vestibular compensation is significantly attenuated by mepyramine and partially mediated by $\mathrm{H} 1$ receptor. Intriguingly, consistent with our results, a significantly larger postural sway has been reported in health subjects treated with $\mathrm{H} 1$-antihistamine, D-chlorpheniramine (Chazot, 2009; Chihara et al., 2013). We therefore suggest that $\mathrm{H} 1$ receptor may be involved in the amelioration of vestibular 
symptoms and actively participate in promotion of vestibular compensation.

Vestibular compensation after unilateral vestibular loss is a complex process involving distributed synaptic, neuronal, and circuit plasticity (Faulstich et al., 2006; Gao et al., 2012). Although precise mechanisms of neural plasticity for vestibular compensation still remain enigmatic, the vestibular commissural systems, which link the MVNs of the two sides, has been strongly implicated in vestibular compensation (Gliddon et al., 2005; Straka et al., 2005; Bergquist et al., 2008; Malinvaud et al., 2010). In the normal state, the reciprocal commissural system, including both inhibitory and excitatory pathways, is conducive to the balance of neuronal activity between bilateral MVN neurons (Fig. 9A; Ris and Godaux, 1998; Gliddon et al., 2005; Gittis and du Lac, 2008; Jamali et al., 2014). Immediately after UL, the ipsilesional MVN neurons lose their excitatory drive from the lesioned primary vestibular afferents and therefore exhibit hypoactivity (Fig. 9B; Ris et al., 1998; Darlington et al., 2002; Lacour et al., 2016). This imbalance in the activity of bilateral MVNs is believed to be a root cause of the severe oculomotor and postural symptoms that immediately follow the unilateral vestibular lesion. Therefore, increasing the excitability of the ipsilesional MVN to compensate for the loss of excitatory vestibular afferent inputs is a major strategy for rebalancing the bilateral MVN activity and recovery of vestibular symptoms. As we and other groups reported previously, $\mathrm{H} 1$ receptor is largely expressed throughout the MVN, and the activation of $\mathrm{H} 1$ receptor induces a significant depolarization and excitation on the MVN neurons (Yabe et al., 1993; de Waele et al., 1993; Wang and Dutia, 1995; X. Y. Zhang et al., 2013). Interestingly, by HPLC analysis of amino acids in samples obtained from unilateral MVN slice superfusates, Bergquist and Dutia (2006) and Bergquist et al. (2006) indirectly suspected a possible involvement of $\mathrm{H} 1 / \mathrm{H} 2$ receptor, presumably expressed on the glycinergic neurons, in the modulation of MVN GABAergic neurotransmission. However, in the present study, we provide direct evidence, in the neuronal and circuit levels, that the $\mathrm{H} 1$ receptor is expressed abundantly in the reciprocal commissural system (Fig. 2). Moreover, the expression of $\mathrm{H} 1$ receptor is selectively increased in the ipsilesional rather than contralesional GABAergic vestibular commissural neurons after UL (Fig. 2). Notably, the excitation induced by $\mathrm{H} 1$ receptor activation is consequently enhanced in the ipsilesional MVN commissural GABAergic neurons (Fig. 3), which send inhibitory commissural projections to contralateral excitatory/inhibitory projection neurons rather than the contralesional inhibitory interneurons that receive excitatory commissural inputs from the ipsilesional side (Fig. 9B; Graham and Dutia, 2001; Malinvaud et al., 2010; Beraneck and Idoux, 2012). We thus speculate that the ipsilesional MVN GABAergic commissural neurons may elevate their responsiveness to histamine by increasing $\mathrm{H} 1$ receptor expression to increase their neuronal firing rates and consequently inhibit the activity of contralesional excitatory/inhibitory projection neurons to help to rebalance the two sides and restore vestibular oculomotor and postural symptoms (Fig. 9B). On the other hand, histamine $\mathrm{H} 1$ receptor expressed in the commissural excitatory neurons that project to the contralateral inhibitory interneurons may not be directly involved in the vestibular compensation (Fig. 9).

Vestibular disorders are very common in the general population and strongly affect the quality of life. However, current pharmacopeia originates from empiric approaches, based upon assumptions rather than from specific targeted actions and well defined molecular mechanisms (Chabbert, 2016). In addition, antivertigo drugs mostly have sedative effects and inhibit vestibular compensation. In this study, we establish a circuit mechanism driven by histamine $\mathrm{H} 1$ receptor in the MVN commissural inhibitory system, which may provide a potential target for therapeutic intervention of vestibular disorders. The $\mathrm{H} 1$ receptormediated asymmetric activation of vestibular commissural inhibitory system may help to rebalance the bilateral MVNs and contribute to vestibular compensation for recovery of both static symptoms and dynamic dysfunction in locomotion and motor coordination. Therefore, our results uncover a previously unknown role for long neglected histamine $\mathrm{H} 1$ receptor in vestibular compensation, and the findings provide a new insight into the postlesion neural circuit plasticity of the CNS and a potential therapeutic target for not only alleviating vestibular symptoms but also promoting vestibular compensation.

\section{References}

Ali AH, Yanoff LB, Stern EA, Akomeah A, Courville A, Kozlosky M, Brady SM, Calis KA, Reynolds JC, Crocker MK, Barak N, Yanovski JA (2010) Acute effects of betahistine hydrochloride on food intake and appetite in obese women: a randomized, placebo-controlled trial. Am J Clin Nutr 92:1290-1297. CrossRef Medline

Altman J, Sudarshan K (1975) Postnatal development of locomotion in the laboratory rat. Anim Behav 23:896-920. CrossRef Medline

Angelaki DE, Cullen KE (2008) Vestibular system: the many facets of a multimodal sense. Annu Rev Neurosci 31:125-150. CrossRef Medline

Bagnall MW, Stevens RJ, du Lac S (2007) Transgenic mouse lines subdivide medial vestibular nucleus neurons into discrete, neurochemically distinct populations. J Neurosci 27:2318-2330. CrossRef Medline

Becker-Bense S, Buchholz HG, Best C, Schreckenberger M, Bartenstein P, Dieterich M (2013) Vestibular compensation in acute unilateral medullary infarction: FDG-PET study. Neurology 80:1103-1109. CrossRef Medline

Beraneck M, Idoux E (2012) Reconsidering the role of neuronal intrinsic properties and neuromodulation in vestibular homeostasis. Front Neurol 3:25. CrossRef Medline

Bergquist F, Dutia MB (2006) Central histaminergic modulation of vestibular function- a review. Sheng Li Xue Bao 58:293-304. Medline

Bergquist F, Ruthven A, Ludwig M, Dutia MB (2006) Histaminergic and glycinergic modulation of GABA release in the vestibular nuclei of normal and labyrinthectomised rats. J Physiol 577:857-868. CrossRef Medline

Bergquist F, Ludwig M, Dutia MB (2008) Role of the commissural inhibitory system in vestibular compensation in the rat. J Physiol 586:44414452. CrossRef Medline

Borel L, Harlay F, Lopez C, Magnan J, Chays A, Lacour M (2004) Walking performance of vestibular-defective patients before and after unilateral vestibular neurotomy. Behav Brain Res 150:191-200. CrossRef Medline

Brandt T, Dieterich M (2017) The dizzy patient: don't forget disorders of the central vestibular system. Nat Rev Neurol 13:352-362. CrossRef Medline

Campos-Torres A, Touret M, Vidal PP, Barnum S, de Waele C (2005) The differential response of astrocytes within the vestibular and cochlear nuclei following unilateral labyrinthectomy or vestibular afferent activity blockade by transtympanic tetrodotoxin injection in the rat. Neuroscience 130:853-865. CrossRef Medline

Chabbert C (2016) Principles of vestibular pharmacotherapy. Handb Clin Neurol 137:207-218. CrossRef Medline

Chazot PL (2009) Advances in histamine pharmacology reveal new drug targets. Br J Pharmacol 157:1-3. CrossRef Medline

Chazot PL (2013) Histamine pharmacology: four years on. Br J Pharmacol 170:1-3. CrossRef Medline

Chen L, Todd M, Halmagyi GM, Aw S (2014) Head impulse gain and saccade analysis in pontine-cerebellar stroke and vestibular neuritis. Neurology 83:1513-1522. CrossRef Medline

Chihara Y, Sato A, Ohtani M, Fujimoto C, Hayashi T, Nishijima H, Yagi M, Iwasaki S (2013) The effect of a first-generation H1-antihistamine on postural control: a preliminary study in healthy volunteers. Exp Brain Res 231:257-266. CrossRef Medline

Curthoys IS (2000) Vestibular compensation and substitution. Curr Opin Neurol 13:27-30. CrossRef Medline

Darlington CL, Smith PF (2000) Molecular mechanisms of recovery from 
vestibular damage in mammals: recent advances. Prog Neurobiol 62:313325. CrossRef Medline

Darlington CL, Dutia MB, Smith PF (2002) The contribution of the intrinsic excitability of vestibular nucleus neurons to recovery from vestibular damage. Eur J Neurosci 15:1719-1727. CrossRef Medline

de Waele C, Serafin M, Khateb A, Yabe T, Vidal PP, Mühlethaler M (1993) Medial vestibular nucleus in the guinea-pig: apamin-induced rhythmic burst firing - an in vitro and in vivo study. Exp Brain Res 95:213-222. CrossRef Medline

Dyhrfjeld-Johnsen J, Gaboyard-Niay S, Broussy A, Saleur A, Brugeaud A, Chabbert C (2013) Ondansetron reduces lasting vestibular deficits in a model of severe peripheral excitotoxic injury. J Vestib Res 23:177-186. CrossRef Medline

Faulstich M, van Alphen AM, Luo C, du Lac S, De Zeeuw CI (2006) Oculomotor plasticity during vestibular compensation does not depend on cerebellar LTD. J Neurophysiol 96:1187-1195. CrossRef Medline

Gao Z, van Beugen BJ, De Zeeuw CI (2012) Distributed synergistic plasticity and cerebellar learning. Nat Rev Neurosci 13:619-635. CrossRef Medline

Gittis AH, du Lac S (2006) Intrinsic and synaptic plasticity in the vestibular system. Curr Opin Neurobiol 16:385-390. CrossRef Medline

Gittis AH, du Lac S (2008) Similar properties of transient, persistent, and resurgent na currents in GABAergic and non-GABAergic vestibular nucleus neurons. J Neurophysiol 99:2060-2065. CrossRef Medline

Gliddon CM, Darlington CL, Smith PF (2005) GABAergic systems in the vestibular nucleus and their contribution to vestibular compensation. Prog Neurobiol 75:53-81. CrossRef Medline

Graham BP, Dutia MB (2001) Cellular basis of vestibular compensation: analysis and modelling of the role of the commissural inhibitory system. Exp Brain Res 137:387-396. CrossRef Medline

Günther L, Beck R, Xiong G, Potschka H, Jahn K, Bartenstein P, Brandt T, Dutia M, Dieterich M, Strupp M, la Fougère C, Zwergal A (2015) $\mathrm{N}$-acetyl-L-leucine accelerates vestibular compensation after unilateral labyrinthectomy by action in the cerebellum and thalamus. PLoS One 10:e0120891. CrossRef Medline

Haas HL, Sergeeva OA, Selbach O (2008) Histamine in the nervous system. Physiol Rev 88:1183-1241. CrossRef Medline

Hoebeek FE, Stahl JS, van Alphen AM, Schonewille M, Luo C, Rutteman M, van den Maagdenberg AM, Molenaar PC, Goossens HH, Frens MA, De Zeeuw CI (2005) Increased noise level of Purkinje cell activities minimizes impact of their modulation during sensorimotor control. Neuron 45:953-965. CrossRef Medline

Jamali M, Mitchell DE, Dale A, Carriot J, Sadeghi SG, Cullen KE (2014) Neuronal detection thresholds during vestibular compensation: contributions of response variability and sensory substitution. J Physiol 592: 1565-1580. CrossRef Medline

Ji MJ, Zhang XY, Chen Z, Wang JJ, Zhu JN (2018) Orexin prevents depressive-like behavior by promoting stress resilience. Mol Psychiatry. Advance online publication. Retrieved August 7, 2018. doi: 10.1038/ s41380-018-0127-0.

Jiang W, Rajguru SM (2018) Eye movements evoked by pulsed infrared radiation of the rat vestibular system. Ann Biomed Eng 46:1406-1418. CrossRef Medline

Kim JS, Zee DS (2014) Clinical practice. benign paroxysmal positional vertigo. N Engl J Med 370:1138-1147. CrossRef Medline

Lacour M (2013) Betahistine treatment in managing vertigo and improving vestibular compensation: clarification. J Vestib Res 23:139-151. CrossRef Medline

Lacour M, Tighilet B (2010) Plastic events in the vestibular nuclei during vestibular compensation: the brain orchestration of a "deafferentation" code. Restor Neurol Neurosci 28:19-35. CrossRef Medline

Lacour M, Helmchen C, Vidal PP (2016) Vestibular compensation: the neuro-otologist's best friend. J Neurol 263:S54-S564. CrossRef Medline

Li B, Zhuang QX, Gao HR, Wang JJ, Zhu JN (2017) Medial cerebellar nucleus projects to feeding-related neurons in the ventromedial hypothalamic nucleus in rats. Brain Struct Funct 222:957-971. CrossRef Medline

Li C, Han L, Ma CW, Lai SK, Lai CH, Shum DK, Chan YS (2013) Maturation profile of inferior olivary neurons expressing ionotropic glutamate receptors in rats: role in coding linear accelerations. Brain Struct Funct 218:833-850. CrossRef Medline

Lian J, Huang XF, Pai N, Deng C (2016) Ameliorating antipsychoticinduced weight gain by betahistine: mechanisms and clinical implications. Pharmacol Res 106:51-63. CrossRef Medline
Macdougall HG, Curthoys IS (2012) Plasticity during vestibular compensation: the role of saccades. Front Neurol 3:21. CrossRef Medline

Malinvaud D, Vassias I, Reichenberger I, Rössert C, Straka H (2010) Functional organization of vestibular commissural connections in frog. J Neurosci 30:3310-3325. CrossRef Medline

Mira E (2008) Improving the quality of life in patients with vestibular disorders: the role of medical treatments and physical rehabilitation. Int J Clin Pract 62:109-114. CrossRef Medline

Panula P, Nuutinen S (2013) The histaminergic network in the brain: basic organization and role in disease. Nat Rev Neurosci 14:472-487. CrossRef Medline

Panula P, Chazot PL, Cowart M, Gutzmer R, Leurs R, Liu WL, Stark H, Thurmond RL, Haas HL (2015) International union of basic and clinical pharmacology. XCVIII: Histamine receptors. Pharmacol Rev 67:601655. CrossRef Medline

Paxinos G, Watson C (2014) The rat brain in stereotaxic coordinates, Ed 7. San Diego: Academic.

Peng SY, Zhuang QX, He YC, Zhu JN, Wang JJ (2013) Histamine excites neurons of the inferior vestibular nucleus in rats by activation of $\mathrm{H} 1$ and H2 receptors. Neurosci Lett 541:87-92. CrossRef Medline

Provensi G, Blandina P, Passani MB (2016) The histaminergic system as a target for the prevention of obesity and metabolic syndrome. Neuropharmacology 106:3-12. CrossRef Medline

Ramos Alcocer R, Ledezma Rodríguez JG, Navas Romero A, Cardenas Nuñez JL, Rodríguez Montoya V, Deschamps JJ, Liviac Ticse JA (2015) Use of betahistine in the treatment of peripheral vertigo. Acta Otolaryngol 135: 1205-1211. CrossRef Medline

Redon C, Lopez C, Bernard-Demanze L, Dumitrescu M, Magnan J, Lacour M, Borel L (2011) Betahistine treatment improves the recovery of static symptoms in patients with unilateral vestibular loss. J Clin Pharmacol 51:538-548. CrossRef Medline

Ris L, Godaux E (1998) Spike discharge regularity of vestibular neurons in labyrinthectomized guinea pigs. Neurosci Lett 253:131-134. CrossRef Medline

Ris L, Wattiez R, Waele Cd, Vidal PP, Godaux E (1998) Reappearance of activity in the vestibular neurones of labyrinthectomized guinea-pigs is not delayed by cycloheximide. J Physiol 512:533-541. CrossRef Medline

Sadeghi SG, Minor LB, Cullen KE (2007) Response of vestibular-nerve afferents to active and passive rotations under normal conditions and after unilateral labyrinthectomy. J Neurophysiol 97:1503-1514. CrossRef Medline

Sajjadi H, Paparella MM (2008) Meniere's disease. Lancet 372:406-414. CrossRef Medline

Straka H, Vibert N, Vidal PP, Moore LE, Dutia MB (2005) Intrinsic membrane properties of vertebrate vestibular neurons: function, development and plasticity. Prog Neurobiol 76:349-392. CrossRef Medline

Strupp M, Zwergal A, Feil K, Bremova T, Brandt T (2015) Pharmacotherapy of vestibular and cerebellar disorders and downbeat nystagmus: translational and back-translational research. Ann N Y Acad Sci 1343:27-36. CrossRef Medline

Tighilet B, Trottier S, Lacour M (2005) Dose- and duration-dependent effects of betahistine dihydrochloride treatment on histamine turnover in the cat. Eur J Pharmacol 523:54-63. CrossRef Medline

Tighilet B, Trottier S, Mourre C, Lacour M (2006) Changes in the histaminergic system during vestibular compensation in the cat. J Physiol 573:723739. CrossRef Medline

Tighilet B, Mourre C, Trottier S, Lacour M (2007) Histaminergic ligands improve vestibular compensation in the cat: behavioural, neurochemical and molecular evidence. Eur J Pharmacol 568:149-163. CrossRef Medline

Wang JJ, Dutia MB (1995) Effects of histamine and betahistine on rat medial vestibular nucleus neurones: possible mechanism of action of antihistaminergic drugs in vertigo and motion sickness. Exp Brain Res 105: 18-24. Medline

Wang Y, Chen ZP, Zhuang QX, Zhang XY, Li HZ, Wang JJ, Zhu JN (2017) Role of corticotropin-releasing factor in cerebellar motor control and ataxia. Curr Biol 27:2661-2669.e2665. CrossRef Medline

Ward B, Zee D (2016) Dizziness and vertigo during MRI. N Engl J Med 375:e44. CrossRef Medline

Wentzel PR, De Zeeuw CI, Holstege JC, Gerrits NM (1995) Inhibitory synaptic inputs to the oculomotor nucleus from vestibulo-ocular-reflexrelated nuclei in the rabbit. Neuroscience 65:161-174. CrossRef Medline 
Yabe T, de Waele C, Serafin M, Vibert N, Arrang JM, Mühlethaler M, Vidal PP (1993) Medial vestibular nucleus in the guinea-pig: histaminergic receptors. II. An in vivo study. Exp Brain Res 93:249-258. CrossRef Medline

Zhang J, Li B, Yu L, He YC, Li HZ, Zhu JN, Wang JJ (2011) A role for orexin in central vestibular motor control. Neuron 69:793-804. CrossRef Medline

Zhang J, Zhuang QX, Li B, Wu GY, Yung WH, Zhu JN, Wang JJ (2016) Selective modulation of histaminergic inputs on projection neurons of cerebellum rapidly promotes motor coordination via $\mathrm{HCN}$ channels. Mol Neurobiol 53:1386-1401. CrossRef Medline

Zhang XY, Yu L, Zhuang QX, Peng SY, Zhu JN, Wang JJ (2013) Postsynaptic mechanisms underlying the excitatory action of histamine on medial vestibular nucleus neurons in rats. Br J Pharmacol 170:156-169. CrossRef Medline

Zhou L, Zhou W, Zhang S, Liu B, Leng Y, Zhou R, Kong W (2013) Changes in histamine receptors ( $\mathrm{H} 1, \mathrm{H} 2$, and $\mathrm{H} 3)$ expression in rat medial vestibular nucleus and flocculus after unilateral labyrinthectomy: histamine receptors in vestibular compensation. PLoS One 8:e66684. CrossRef Medline
Zhuang QX, Wu YH, Wu GY, Zhu JN, Wang JJ (2013) Histamine excites rat superior vestibular nuclear neurons via postsynaptic $\mathrm{H} 1$ and $\mathrm{H} 2$ receptors in vitro. Neurosignals 21:174-183. CrossRef Medline

Zhuang QX, Xu HT, Lu XJ, Li B, Yung WH, Wang JJ, Zhu JN (2018a) Histamine excites striatal dopamine D1 and D2 receptor-expressing neurons via postsynaptic $\mathrm{H} 1$ and $\mathrm{H} 2$ receptors. Mol Neurobiol 55:80598070. CrossRef Medline

Zhuang QX, Li GY, Li B, Zhang CZ, Zhang XY, Xi K, Li HZ, Wang JJ, Zhu JN (2018b) Regularizing firing patterns of rat subthalamic neurons ameliorates parkinsonian motor deficits. J Clin Invest 128:5413-5427. Medline

Zwergal A, Schlichtiger J, Xiong G, Beck R, Günther L, Schniepp R, Schöberl F, Jahn K, Brandt T, Strupp M, Bartenstein P, Dieterich M, Dutia $M B$, la Fougère $C$ (2016) Sequential $\left[{ }^{18} F\right] F D G$ microPET wholebrain imaging of central vestibular compensation: a model of deafferentation-induced brain plasticity. Brain Struct Funct 221:159170. CrossRef Medline 